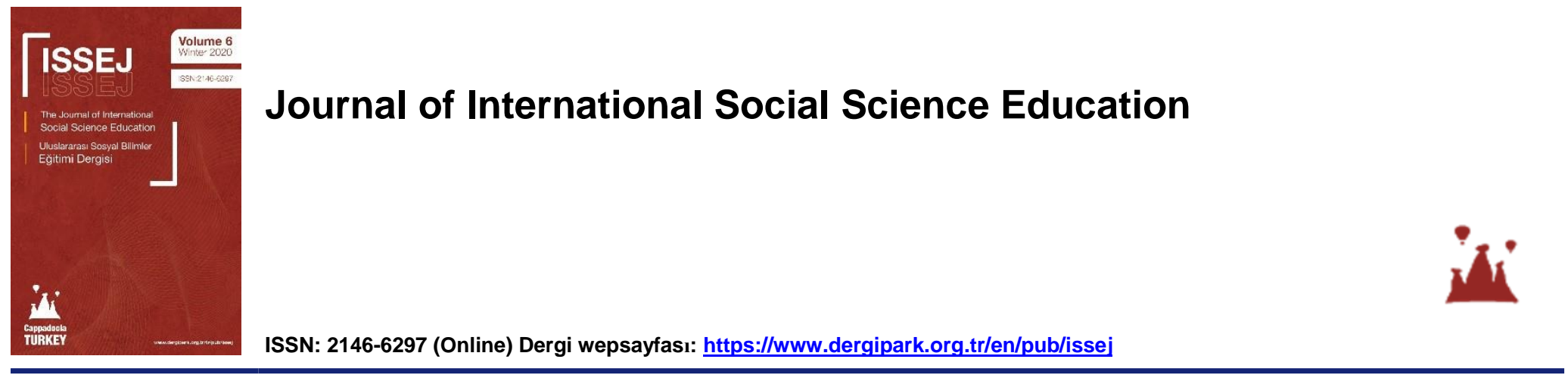

\title{
Oluşturma-Geliştirme Açısından Sosyal Bilgiler Öğretiminde Bir Öğretim Materyali Olarak Çizgi Roman Kullanımı
}

\section{Ali Ekber GÜLERSOY Berkay TÜRKAL}

Önerilen atıf: Türkal, B. \& Gülersoy, A.E. (2020). Oluşturma-Geliştirme Açısından Sosyal Bilgiler Öğretiminde Bir Öğretim Materyali Olarak Çizgi Roman Kullanımı, Uluslararası Sosyal Bilimler Eğitimi Dergisi, 6(2), 299-326. DOI: 10.47615/issej.839497

Makale linki: https://doi.org/10.47615/issej.839497

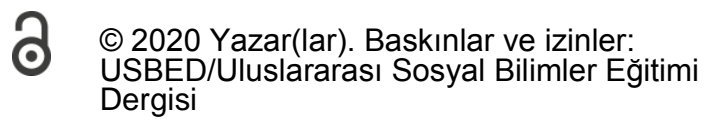

USBED/Ulusslararası Sosyal Bilimler Eğitimi Dergisi hakemli bir çevrimiçi dergidir. Bu makale araştırma, öğretim ve özel çalışmalar macıyla kullanılabilir. Makalenin içeriğinden yanilızca yazarlar sorumludur Dergi makalelérin telif hakkına sahiptir. Yayıncı, arasstırma materyalinin kullanımıyla bağlantılı veya doğrudan veya dolaylı olarak ortaya çıkan herhangi bir kayıp, işlem, talep veya masraf veya zarardan sorumlu tutulamaz. 


\section{Oluşturma-Geliştirme Açısından Sosyal Bilgiler Öğretiminde Bir Öğretim Materyali Olarak Çizgi Roman Kullanımı}

\section{Ali Ekber GÜLERSOY}

Buca Eğitim Fakültesi Türkçe ve Sosyal Bilimler Eğitimi Bölümü, Sosyal Bilgiler Eğitimi Anabilim Dalı, Dokuz Eylül Üniversitesi, Buca, İzmir, 35380, Türkiye

\section{Berkay TÜRKAL우}

Bahçehir Koleji, Güzelbahçe, İzmir, 35310, Türkiye

\begin{abstract}
ÖZ
Araştırmanın amacı, Sosyal Bilgiler dersinin kazanımlarına yönelik materyal olusturularak çizgi romanlarda bulunması gereken özellikleri belirlemek ve oluşturulan materyallerin uygun öğretim yöntem ve tekniklerini desteklemesine ilişkin öneriler getirmektir. Nitel paradigmaya dayalı betimsel model kullanılan bu çalışmada, araştırma sırasında elde edilen veriler, betimleyici ve yorumlayıcı bir teknikle çözümlenmiştir. Bu çalışmanın amaç ve alt amaçlarına ulaşmak için sorulan sorulara cevap bulabilmeye yönelik ilgili yayın ve araştırmalar taranmıştır. Elde edilen verilerle ilk olarak "Sosyal Bilgiler öğretimine yönelik çizgi romanların öğretim materyali olma kriterlerini karşılayacak biçimde nasıl oluşturulabileceği?" sorusuna yanıt aranmıştır. İkinci olarak, altıncı sınıf Sosyal Bilgiler ders kitabının "Sosyal Bilgiler Öğreniyorum" ünitesi kazanımlarına yönelik, öğretim materyali geliştirme ilkelerine uygun biçimde örnek çizgi romanlar oluşturulmuştur. Bu araştırma öğretim materyali olarak çizgi roman geliştirme sürecini ortaya koyması ve doğrudan kazanımlar için çizgi roman oluşturmaya yönelik olması bakımından orijinallik arz etmektedir. CCizgi roman oluşturma sürecinde öğretim materyali geliştirme ilkeleri yanında çağdaş öğretim yöntem ve teknikleri de dikkate alınmıştır. Söz konusu çizgi romanlar seçtiğimiz öğretim yöntem ve tekniklerine uygun olarak tarafımızca geliştirilmiştir. Bu cerçevede Sosyal Bilgiler öğretimine yönelik çizgi romanların geliştirilmesine ve geliştirilen çizgi romanların derslerde uygulanmasına yönelik önerilerde bulunulmuştur.
\end{abstract}

MAKALE TARİHİ

Geliş tarihi 12 Aralık 2020

Kabul tarihi 18 Aralık 2020

Yayım tarihi 31 Aralık 2020

ANAHTAR KELIMER

Sosyal bilgiler, yazılı materyal, görsel materyal, çizgi roman, öğretim yöntem ve teknikleri

Makale Türü

Araştırma makalesi 


\section{Use of Comics as a Teaching Material in Social Studies Education in Terms of Its Composition and Development}

\section{Ali Ekber GÜLERSOY}

Buca Faculty of Education, Department of Turkish and Social Fields Education, Social Studies Education, Dokuz Eylül University, Buca, İzmir, 35380, TURKEY

\section{Berkay Türkal}

Bahçeşehir College, Güzelbahçe, İzmir, 35310, TURKEY

\begin{abstract}
Purpose of this study is to determine features which should be on comics by forming material for goals of Social Studies course and to bring forward proposals for supporting of the formed materials to the appropriate teaching methods and techniques. Data obtained were analyzed in a descriptive and interpretative techniques. We reviewed relevant publications and studies to find an answer to questions which were asked to reach goals and sub-goals of this study. Firstly, we sought answer to question "how can comics for Social Studies education be created in a way they would meet the criteria to be teaching material?". Secondly, we created sample comics for goals of the unit "I am Learning Social Studies". This study is of authenticity in that it presents process to develop comics and is for developing comics for direct goals. Contemporary teaching methods and techniques were also taken into consideration. The said comics were developed by us in compliance with the teaching methods and techniques we chose. And, we made suggestions for developing comics for Social Studies education and for implementing the developed comics in courses.
\end{abstract}

ARTICLE HISTORY

Received 12 December 2020

Accepted 18 December 2020

\section{KEYWORDS}

Social studies, written material, visual material, comics, teaching methods and techniques

Type of the Paper

Research article

\section{CONTACT Ali Ekber GÜLERSOY}

(c) 2020 Ali Ekber Gülersoy, Berkay Türkal.

This is an Open Access article distributed under the terms of the Creative Commons Attribution-NonCommercial-NoDerivatives License (http://creativecommons.org/licenses/by-nc-nd/4.0/), which permits non-commercial re-use, distribution, and reproduction in any medium, provided the original work is properly cited, and is not altered, transformed, or built upon in any way 
Sosyal Bilgiler, ilköğretimde sorumluluk bilinci gelişmiş yurttaşlar yetiştirmek için sosyal bilimlerin elde ettiği bulgulara göre, öğrencilerin yaşamla ilgili belli başlı bilgi, beceri, davranış ve değerlerin verildiği bir alandır (Erden, 1997: 8). Bunun yanında Sosyal Bilgiler, demokratik yurttaş yetiştirmek için gerekli tüm becerileri geliştirmeyi hedef alan bir derstir (Öztürk, 2012: 9). Pek çok farklı tanımı olmasına karşın, ortak ifadelerle Sosyal Bilgilerin ne olduğunu açıklamak mümkündür. Sosyal Bilgilerin tanımında geçen ana ifadeler şunlardır: Etkin yurttaş yetiştirme, kültürleme, öğrenciye uygunluk, bilgi esaslı, yöntem, zaman, alan ve ders boyutu (Tay, 2010: 10).

Ülkemizde ilköğretim kademesinden itibaren temel derslerden olan Sosyal Bilgiler dersi önemli bir konuma sahiptir. Sosyal bilgiler yurttaşlık becerilerini geliştirmek için sosyal ve beşeri bilimlerin harmanlandığı bir alandır. Beşeri ve pozitif bilimlerin bulguları, Sosyal Bilgilere uygun biçimde derlenir. Böylece Sosyal Bilgiler öğrencilere bilgi temelli, doğru karar alabilme yetilerini geliştirme yolunda rehberlik eder, hoşgörüyü geliştirir (Akdağ, 2009: 3).

Sosyal bilimler kavramını tarif etmenin zor olmasının yanında Sosyal Bilgiler kavramıyla karıştırıldığı da bilinmektedir. Ancak bunlar birbirlerinden farklıdır. Sosyal bilimler insana dair bilgileri açığa çıkarırken; Sosyal Bilgiler, Sosyal Bilimlerin bulgularını, insanlar için gerekli olan temel ve ortak öğelerini kapsar (Kısakürek, 1989: 5). "Sosyal Bilim" kavramının ne olduğunu tarif etmek mümkün değilse de toplum içinde yaşayan kişileri, insan gruplarını, topluluklarını ve toplumlarını irdeleyen bir bilim dalıdır denilebilir (Duverger, 1999: 7). Sosyal Bilgiler öğretim planlanması yapılırken, bu planlamanın temelini sosyal bilimler oluşturur. Sosyal Bilimlerin öğretim amaçları, Sosyal Bilgiler öğretiminin amaçlarını ortaya koyabilmektedir. Sosyal Bilgilerde ele alınan sözcükler, kavramlar ve genellemeler ile kullanılan araştırma süreçleri ve çalışma becerilerine ilişkin kaynaklar sosyal bilimlerden elde edilmektedir (Sağlamer, 1983: 25). Sosyal Bilgilerin konusu toplumsal hayatı düzenleyen ilke ve genellemeler olabilir. Fakat Sosyal Bilgilerin konuları yaşanılan ülkenin durumuna göre oluşturulur. Böylece sosyal bilimlerin ortaya koyduğu tüm ilke ve önermeler Sosyal Bilgilerin içeriğine girmeyebilir. Yani Sosyal Bilgiler, sosyal bilimler disiplinlerinden seçilmiş bilgilerden oluşmaktadır (Sönmez, 1999: 4).

Sosyal bilimlerin kapsamına giren söz konusu disiplinler şunlardır; antropoloji, coğrafya, dil bilimi, eğitim bilimleri, ekonomi, iletişim bilimleri, siyaset bilimi, tarih, uluslararası ilişkiler, psikoloji, sosyoloji, müzikoloji, hukuk ve suç bilimi. Sosyal bilimlerin kapsamı içine giren disiplinlerin birbirinden ayrıldıkları en önemli kısım insanı ele aldıkları boyuttur (Tay, 2010: 6).

\section{Türkiye'de Sosyal Bilgiler Anlayıșı}

Türkiye'de Sosyal Bilgiler ders olarak ilk defa 1968 yılında okutulmaya başlanmıştır. 1968 yılından öncesinde 4. ve 5. sınıflarda tarih, coğrafya, yurttaşlık bilgisi olarak verilen konular, aralarındaki yakın ilişkileri ve öğrenciye uygunluğu açısından bir araya getirilerek Sosyal Bilgiler dersi altında toplanmıştır. Söz konusu ders, disiplinlerarası ve çok disiplinli yaklaşıma göre yapılandırılmıştır.

Yeni Sosyal Bilgiler programının, eski programa göre güçlü yönleri mevcuttur; program çok disiplinli ve disiplinler arası program desenine göre hazırlanmıştır. Yeni sosyal bilgiler programının esnek yapısıyla bilgi toplumuna uygun olduğu görülür. Çoklu zeka kuramına uygun olarak hazırlanması ise bir başka güçlü tarafıdır. Yine öğrenciye; bilgiye ulaşma, öğrenmeyi öğrenme, sosyalleşme, katılım becerisi, organizasyon ve işbirliği becerilerini geliştirme bakımından destek sağladığı görülmektedir. Öğrencilerin hayal güçlerini harekete geçirme potansiyeline sahip olan yeni program, araştırma, değerlendirme, analiz etme, sorgulama, problem çözme vb. becerileri kazandırabilme özelliği taşımaktadır. Bunların yanında yeni Sosyal Bilgiler programının ürünü değil 
süreci değerlendiriyor olması yeni programın eski programa göre bir başka üstün tarafıdır (Semenderoğlu ve Gülersoy, 2005: 160).

\section{Çizgi Roman}

Popüler kültürde kendine derin bir yer bulmuş olan çizgi romanın en kısa tanımlarından birisi; çizgi roman, herhangi bir hikâye ya da öykünün resim ya da çizgiler aracılığıyla anlatılmasıdır (Alsaç, 1994: 44). Çizgi roman yazı ve resmin birleşiminden oluşan bir kurgu sanatıdır (Ceran ve Cantek, 2004: 28). Çizgi romanın ne olduğu üzerine en yaygın ve kabul gören anlayış, çizgi romanın art arda gelen resimler arasındaki bağlantının anlatıldığı hikâye olarak tanımlanmasıdır (Özşen ve Sayın 2004: 77).

Çizgi romanlar zaman içerisinde iki önemli anlatım biçimi oluşturmuştur. Bunlardan ilki kahraman çizgi romanlarıdır. Kahraman çizgi romanlarında kahramanlar çoğu zaman "sıradan" öğeler barındırır, bu haliyle kahramanlar okuyucudan biri gibidir. Zaten bu nedenle okuyucu, kahramanla kendisi arasında bir bağ kurabilir. Verdikleri mücadele, zıtların keskinliği ilkesine dayandırılır. Aksiyon çoğu zaman zirvededir ve hikâye arada kurguyu desteklemesi amacıyla mizah unsurları barındırabilir. Bir diğer biçim ise yaratıcı çizgi romanlarıdır. Bu örnekler, daha çok 1960'larla birlikte kendilerini göstermeye başlamışlardır. Belli bir yaratıcı tarafından oluşturulan, yaratıcı çizgi romanlarında gerçek yaşam sıradanlığı, kahraman çizgi romanlarına göre çok daha yoğundur. Bu nedenle okur, hikâyenin gerçek dünyada geçtiğini sürekli hatırlar. Zaman içerisinde bu iki biçim birbirlerine yaklaşmışlardır. Hatta "Ken Parker" gibi serilerde iç içe geçmişlerdir (Cantek, 2014: 27-28).

Çizgi romanlar kendilerine özgü evren yaratma gücüne sahiptir (Ceran ve Cantek, 2004: 28). Evren yaratma güçleri o kadar yüksektir ki serinin takipçileri, söz konusu kurgu evrenlerinin doğasını bilebilir ve gelişecek olan olaylara karşı öngörüde bulunabilirler. Bu kurgusal evrenlerden en bilinenlerinden birisi "Conan"dır. Söz konusu evrende gerçek hayattan esinlenilmiş ırklar ve devletler vardır. Öte yandan bazı çizgi roman şirketlerinin çıkardığı çizgi romanların iç içe geçmesiyle oluşmuş daha büyük evrenler de vardır. Marvel şirketinden "Marvel Universe", DC Comics şirketinden "DC Universe" bunlardan en bilinenleridir.

Metni desteklemek için resimlerin kullanıldığı ilk örnekleri 17 . yüzyılda William Hogart'in The Rake Progress (1735) ve Marriage a la Mode (1734) adlı çalışmalarında görebiliriz. $\mathrm{Bu}$ eserler karikatür sanatının da kökenini oluşturmuşlardır. Hogarth'ın öncülüğünü yaptığı bu türü sonraki dönemlerde Thomas Rowlandson, James Gillray ve Töpffer gibi sanatçılar geliştirerek devam ettirmişlerdir (Cantek, 2014: 32). Bu bağlamda çizgi roman sanatının Avrupa'dan çıktığ 1 söylenebilir, ancak ona bildiğimiz biçimini veren Amerika çıkışlı eserler olmuştur. 1896'da ilk çizgi bant olarak kabul edilen Richard F. Outcault'ın Hogan's Alley adlı eseri New York Journal'da yayınlanmıştır (Cantek, 2014: 33-34) Serüven tarzının en etkili ilk örneklerinden olan Tarzan of the Apes ise 1929 yılında Hal Foster tarafından çizilmiştir. Pek çok Amerikan gazetesinde aynı anda yayınlanmaya başlanan bu seri ciddi bir okuyucu kitlesine ulaşmıştır (Alpin, 2006: 573). 1930’lu yıllarda çizgi romanlarda büyük oranda serüven anlayışı hâkim olmuştur.

Çizgi romanlar doğaları gereği popüler kültürün hedef kitlesi için kolaylıkla erişilebilir oldukları için tarihsel dönem içerisinde güçlü propaganda araçları olarak kullanılmışlardır. İkinci Dünya Savaşı yıllarında ortaya çıkan Kaptan Amerika, tarihsel açıdan çizgi romanın propaganda gücünü gözler önüne sermektedir. İlk kez 1941 yılında Joe Simon ve Jack Kirby tarafından yaratılan çizgi roman, belirgin biçimde Amerikan vatanseverliğinin göstergelerinden birisi haline gelmiştir (Alpin, 2006: 331). Kaptan Amerika, Amerikan gençlerini orduya katılmaları için teşvik etmiştir.

Günümüzde çizgi roman yayını bir dönüşüm yaşamaktadır ve pek çok yayınevi farklı türden çizgi roman baskılarına yer vermektedir (Ayrıntı Yayınları, Büyülü Dükkan, Çizgi Düşler, Gerekli Şeyler, İthaki Yayınları, JBC Yayıncılık, Marmara Çizgi, NTV Yayınları, Panama Yayıncılık, Yapı Kredi Yayınları vb.). NTV Yayınları'nın dünya klasiklerinin çizgi roman versiyonlarını basması Türk toplumunun özellikle gençlerin okuma 
alışkanlıklarını değiştirebilecek niteliktedir.

\section{Öğretimde Materyal ve Çizgi Roman}

Öğretim sürecinde söz konusu materyaller çoğu zaman öğretimi desteklemek amaciyla kullanılır. Öğretim ilke ve yöntemlerine göre tasarlanmış öğretim materyalleri, öğrenmeöğretme sürecini çeşitlendirir, öğrenmeyi arttırır (Yalın, 2009: 82). Öğrenme-öğretme sürecinde materyal kullanımının sağladığı yararları ortaya koyan birçok çalışma mevcuttur. Derslerde öğretim materyallerine yer vermenin, konuları daha basit, somut hale getirdiği bilinmektedir. Ayrıca birden fazla duyu organına hitap etmesi bakımından öğrencinin dikkatini toplamaya yardımcı olup, güdülenmelerini de kolaylaştırmaktadır (Yıld1z, 2004: 13; İlhan, 2016: 13). Bu nedenle her geçen y1l öğretim faaliyetlerinde görsel öğe kullanımında artış yaşanmaktadır. Çizgi romanın diğer bileşeni olan görsel öğesi öğretimi desteklemede çok kuvvetli bir materyaldir. Öğretimde sadece yazı ya da görsel materyal tek başına yeterli olmamaktadır. Ancak her ikisi bir arada kullanıldığ zaman etkinin arttığı bilinen bir gerçektir (İşler, 2003: 9).

Yapılan çalışmaların çoğunda çizgi roman kullanımının güdülenmeyi artırdığı ifade edilmektedir. Ancak söz konusu çalışmaların hepsinin birleştiği ortak nokta, çizgi romanların büyük bir özenle hazırlanması gerekliliğidir (Ardasheva, Bowden, Morrison ve Tretter, 2015: 40; Berson ve Berson, 2011: 113; Botzakis, 2013: 70; Carr, 1958: 13; Cirigliano, 2012: 29; Dougherty, 2002: 260; Griva, Alevriadou ve Semoglou, 2012: 25; İlhan, 2016: 40; Tatalovic, 2009: 13; Trent ve Kinlaw, 1979: 19; Ünal ve Demirkaya, 2019: 92; Wright, 1979: 160). Çizgi romanı oluşturan iki önemli bileşen yazı ve resimdir. Çizgi romanda yazının, çocukların akademik dile geçişine zemin hazırladığ düşünülmektedir. Günlük hayatta ve çizgi romanlarda geçen kelimeleri karşılaştıran çalışmalar çizgi romanlarda kullanılan dilin yapı ve kelime bakımından epeyce zengin olduğunu göstermektedir (Hayes \& Ahrens; aktaran, Çetin, 2010: 196). Çizgi romanlar öğrencilerin evrensel değerler kazanmasında etkili bir yaşantı sağlayabilirler. Nitekim çizgi romanın etkili olmasını sağlayacak iki önemli bileşenden birisi hikâyedir. Edebi metin, gerçek hayatta benzerleri olan kurgusal bir evreni ve bu evrenin karakterlerini sunarak öğrencinin hayal dünyasının gelişmesine katkı sağlar ve yaşantı zenginliği katar. Bu yaşantı zenginliği bireye evrensel değerleri kazandırır (Somuncu, 2010: 197).

Farklı türlerde öğretim materyali kullanımı, farklı özelliklerde olan bütün öğrencilerin başarılarının artmasına neden olabilecek ve bu da eğitim-öğretimde başarıyı artırabilecektir. Ayrıca derslerde öğretim araç-gereç ve materyallerinin etkin kullanımı ile öğrencilerin bilgiye ulaşma yollarını bilen bireyler olarak yetiştirilmeleri sağlanacaktır (Çelikkaya, 2013: 45-47).

Öğretim ilke ve yöntemlerine göre tasarlanmış öğretim materyalleri, öğrenme-öğretmen sürecini çeşitlendirir, öğrenmeyi arttırır. Öğretim materyallerinin sağladığ (2009: 82-90) şu şekilde siralar:

- Çoklu öğrenme ortamı sağlamaları,

- Öğrencilerin bireysel ihtiyaçlarının karşılanması konusunda yardımcı olmaları,

- Dikkat çekmeleri,

- Hatırlamayı olumlu yönde etkilemeleri,

- Soyut kavramları somutlaştırmaları,

- Zamandan ekonomiklik sağlamaları,

- Güvenli gözlem yapma olanağı sunmaları,

- Farklı zamanlarda birbirleriyle tutarlı içeriğin sunulmasını sağlamaları,

- Uzun ömürlü olup yeniden kullanılabilmeleri,

- İçeriği basitleştirerek anlaşılmalarını olumlu yönde etkilemeleri.

Çelikkaya (2013) ise araştırmasında öğretim araç-gereç ve materyallerinin yararlarını öğrenci, öğretmen ve dersin işlenişi açısından ele almıştır. $\mathrm{Bu}$ açıdan bakıldığında; öğrenci açısından öğretim araç-gereç ve materyallerinin faydaları; hızlı öğrenmeyi sağlaması, öğrenme oranlarını artırması, grupla çalışma fırsatı yaratması, psikomotor 
becerileri geliştirmesi, kalıcı öğrenmede yardımcı olması, tekrar yapma şansı vermesi, birden çok duyu organını işe koşması, bilgiyi kazanmada istekli hale getirmesi, güdülenme düzeyini artırması, kolay öğrenmede yardımcı olması, eleştirel düşünme, araştırma ve yaratıcılık gibi becerilerin gelişimine katkıda bulunması ve benzeridir (Çelikkaya, 2013: 48-49).

Öğretmen açısından öğretim araç-gereç ve materyallerinin faydalarını öğretmenlerin mesleklerinden zevk almasına katkı sağlaması, önemli noktaları hatırlamasına yardımcı olması, dersleri daha rahat ve kolay anlatmalarını sağlaması, dersi daha kontrollü bir şekilde işlemesini kolaylaştırması, zaman ve dikkatini öğrencilerinin bireysel ihtiyaçlarının giderilmesine yönlendirmesini sağlaması, zaman ve maliyetten tasarruf sağlaması vb. olarak sıralayabiliriz (Çelikkaya, 2013: 50-51).

Araç, eğitimi destekleyecek olan bir unsurdur. Araçlar öğretmenin yerini tutamazlar. Sadece öğretmenin gücünü arttırır ve öğretmene yardım ederler. Üretilecek olan araçlar, öğrenme-öğretme faaliyetlerini izletmelidir. Eğitim, üretilecek olan materyalden daha ön planda olmalıdır (Koşar ve Çiğdem, 2003: 42).

Öğrenme-öğretme durumlarında bir araca ihtiyaç olup olmadığını belirlemek için dersin veya konunun genel amaçları; bu amaçlara ulaşıldığını gösteren hedef davranışlar; ders içeriği ya da konularda verilmek istenilen mesajların niteliği dikkate alınır. Ayrıca öğrencilerin durumları, özellikleri; öğretim faaliyetlerinde kullanılabilir olan araçların mesaj, iletim, potansiyel ve sınırlılıkları göz önüne alınarak bir değerlendirme yapılır (Koşar ve Çiğdem, 2003: 42).

Öğretim materyallerinin kaliteli ve amacına uygun olarak hazırlanması gereklidir. Çünkü ancak bu şekilde hedeflenen faydalar sağlanabilir (Örten ve diğerleri, 2013: 71). Öğretim materyallerinin hazırlanmasındaki ilkeler, materyalin türüne bağlı olarak değişebilmesine karşın, her türlü öğretim materyalinin geliştirilmesinde göz önünde tutulacak temel ilkeler mevcuttur. Bu ilkeler:

- Tam ve doğru bilgi vermesi,

- Objelerin ilk bakışta kavranabilmesi,

- Öğrencinin en az çaba ile kavrayabilmesi,

- En az maliyetle elde edilebilmesi,

- Konuyu meydana getiren unsurların bütünlük göstermesi,

- Materyaller içindeki unsurlar arası uyum olması,

- Kullanılan renklerin uyumlu ve abartısız olmasi,

- Kullanılan yazının açık ve net olması,

- Resimlerde; çizimlerde ve yazılarda dikkat çekmek istenilen yerlerin değişik renklerle gösterilmesi (Koşar ve Çiğdem, 2003: 44-45),

- Basit, sade ve anlaşılabilir olması,

- Önemli ve özet bilgilerle donatılmış olması,

- Görsel özelliklerin materyalin önemli noktalarını vurgulamak amacıyla kullanılması, aşırı kullanımdan kaçınılması,

- Kullanılan öğelerin, öğrencinin eğitimsel durumlarına uygun olması ve öğrencinin gerçek hayatıyla tutarlılık göstermesi,

- Öğrenciye alıştırma ve uygulama firsatı sağlaması,

- Elverdiği kadar gerçek hayatı yansıtması,

- Tüm öğrencinin ulaşımına ve kullanımına açık olması,

- Öğrencilerin de kullanabileceği düzeyde basit olmas1,

- Materyallerin dayanıklı hazırlanması (Yanpar, 2009: 155-159),

- İçinde yer alan bilgilerin doğru ve güncel olması,

- Gerçek yaşamı yansıtması,

- Dersin ve konunun hedeflerine uygun olmasi,

- Materyalin pratik, kullanışlı hazırlanması,

- Öğrencilerin pedagojik özelliklerine uygun olması, 
- İlgi çekici olması ve göze hoş gelmesi,

- Taşınabilir nitelikte olması,

- Öğretim yöntemlerine uygun olması,

- Gerektiğinde kolaylıkla geliştirilebilir ve güncelleştirilebilir olması (Örten ve diğerleri, 2009: 71-75),

- Somut elle tutulan materyaller olması şeklinde listelenebilir (Çapar ve Gümüş, 2016: 80).

\section{Öğretim Materyallerinde Yazı Öğeleri}

Yazı öğelerinin bilinçli biçimde kullanılması hem öğretmen hem de öğrenciler için bilgiyi sunma, saklama, hatırlamayı kolaylaştırma gibi pek çok işlemi ustaca, sıkılmadan yapabilme yeteneği kazandıracaktır (Yalın, 2009: 82). Yazılı materyallerin en önemli avantajları yaygın, ucuz, kolay ulaşılabilir ve çoğaltılabilir olmalarıdır (Yanpar, 2009: 111).

Yazılı bir öğretim materyalinin öğretim faaliyetleri açısından etkili olabilmesi için materyalin okunma bakımından durumu, içeriği ve tasarım unsurları önemlidir (Yalın, 2009: 150). Cümleler kurallı ve yalın olmalıdır. Öğrenci seviyesine hitap etmelidir. Mümkün olduğu kadar Türkçe kökenli kelimelerden oluşmalıdır (Demir ve Akengin, 2011: 13-14).

Yazılı materyallerin seçiminde dikkat edilmesi gereken hususlar şunlardır: Eğitim programına uygunluğu, güncel olması, içerdiği dil, anlatım biçimi, öğrenci için eğitimsel düzeye uygunluğu ve görselliğin kontrolü (Yanpar, 2009: 111).

Yazılı materyallerin etkili olabilmesi için tasarımında dikkate alınması gereken unsurlar ise şunlardır:

Tutarlılık: Mümkün olduğunca değişik sayfa düzeni ve yazı biçimi kullanılmamalıdır. Biçimsel bakımdan tutarlılık göstermelidir.

Sayfa Düzeni: Metindeki paragraflar birbirinden kolayca ayırt edilebilmelidir.

Görsel Materyaller: Fazla ayrıntı görselin anlaşılmasını güçleştirecektir.

Yazı stili: Her paragrafın başında, o paragrafla ilgili özet niteliğinde bilgiye yer verilmeli, her paragraf kendi içerisinde bir bütün olmalıdır. Teknik kelimelerse tanımlamaları ile birlikte verilmelidir.

Yazı Türü ve Boyutu: Basit tasarımlı yazı tipleri seçilmelidir. Basit tasarımlı yazılar, harflerin daha kolayca ayırt edilmesini ve metnin rahat okunmasını sağlar. Basılı materyaller için ideal yazı boyutu 10-12 puntodur.

Vurgulama: Önemli fikirler vurgulanmalıdır. Bu sayede öğrencilerin önemli noktayı ya da fikirleri bulmaları kolaylaşmış olur. Uzun metinlerin vurgulanmasında büyük harf kullanımı (harflerin aynı boyutta olmasından okumayı zorlaştırır) ve altını çizme tekniğinin kullanımından kaçınılmalıdır. Bir vurgulama türü hangi amaçla kullanılmışsa o amaçla kullanılmaya devam edilmelidir. Eğer vurgulama türünde tutarlı olunmazsa, söz konusu vurgulama biçimi önemini yitirecektir (Yalın, 2009: 150-155).

\section{Öğretim Materyallerinde Görsel Öğeler}

Öğrenme \% 83 görme, \% 11 işitme, \% 3,5 koklama, \% 1,5 dokunma, \% 1 tatma duyularıyla edinilir (Koşar ve Çiğdem, 2003: 37). Öğrenmede görme duyusuna hitap edecek etkin materyaller tercih etmek büyük önem arz etmektedir. Ders konusunun anlatımı için öncesinde ilgili temel noktalar belirlenmeli ve görsel materyal desteği hazırlanmalıdır (Savaş, 2007: 160).

Günümüzde resim ve grafiklerle desteklenen yayınların tercih edilmesinin sağladığ1 üstünlük, gazete, dergi ve reklam yayınlarındaki örneklerle ortadadır. $\mathrm{Bu}$ nedenle özellikle eğitim ve öğretim amacı taşıyan yayınların, yeteri kadar göz alıcı ve anlatım bakımından ilginç olması gerekir. Bazı okuyucuların, okuma güçlükleri ve okumaya karşı isteksizlikleri de göz önüne alındığında, kitap ve diğer yayınları biçim, resim, grafik, renk ve sayfa düzeni gibi öğelerle çekici hale getirmenin önemi daha iyi anlaşılacaktır (Ceyhan 
ve Yiğit, 2003: 89).

Görsel materyallerin kavramları somutlaştırabilmesi, kavramlar arasındaki ilişkileri görme imkânları sağlayabilmesi, dikkati çekebilmesi ve sürdürebilmesi, rahat taşınabilmesi ve kolayca üretilebilmesi gibi faydaları vardır (Yanpar, 2009: 111).

Öğrencilerin hangi uyarıcılara odaklandıklarını belirlemek kolay olmayacağı için görsel materyallerin tasarımında, mesajla doğrudan ilgisi olmayan ya da önemsiz öğeler çıkarılmalıdır. Öğretim hedeflenerek tasarlanacak olan bir görsel materyalde nesnelerin anlamsal boyutu, gerçeklik derecesinden daha büyük önem arz eder (Yalın, 2009: 119). $\mathrm{Bu}$ nedenle tasarlanacak olan görsel materyalde anlamsal boyutu temel almak uygun olacaktır.

Görsel materyallerin tasarım öğeleri çizgi, alan, şekil, boyut, doku ve renkten oluşmaktadır.

Çizgi: Çizgiler algılamada ayırt edicilik için gerekli bir öğedir. Çizgiler hareketi ve hareket yönünü ortaya koyan bir etki oluştururlar. Yatay çizgiler genişliği; dikey çizgiler yüksekliği artırıcı etki yaratmaktadır. Eğik çizgiler ise dengesizlik etkisi yaratır (Yanpar, 2009: 154).

Şekil: Anlatılmak istenilen duruma göre, bazen basit şekiller detaylı şekillerden çok daha etkili olur. Çünkü basit olan şekiller, karmaşık olan şekillere göre daha kolay anlaşılır ve daha kolay hatırlanır (Örten ve diğerleri, 2009: 78 ).

Alan: Boşluk, algılamayı kolaylaştıran bir unsurdur. Materyalde odak öğenin dışında kalan boşluklar, odak noktanın vurgulanmasını sağlar (Yanpar, 2009: 154). Aynı zamanda boşluklar kalabalık ve karışıklık duygusuna da engel olur (Örten ve diğer., 2009: 78 ).

Boyut: Materyalde yer alan cisimlerin boyutuna iletilmek istenilen mesaja göre karar verilmelidir (Örten ve diğer., 2009: 79 ).

Doku: Görsellerin birçoğu iki boyutlu olmasına rağmen, bu görsellerde doku veya gerçek materyaller kullanılarak üçüncü bir görünüş boyutu oluşturulabilir (Örten ve diğer., 2009: 79 ).

Renk: Renkli görsel öğeler, siyah beyaz olanlara göre daha etkili olmaktadır (Güneş, 2002: 116). Renkler fazla kullanıldığında dikkat dağıtabilir. Buna karşın renk, algılama üzerinde önemli bir etki yaratır. Renk kullanımı ile ilgili dikkat edilmesi gerekenler şunlardır:

- Renkler her zaman ilgi çekicidir ve dikkat edilmelidir,

- Renklerde yaratılacak zitlıklar önemli bilgileri ayırt etmede etkili olabilir,

- Her bir bilgi türü bir renkle gösterilebilir,

- En önemli bilgiler daha canlı renklerle belirtilebilir,

- Bir materyalde çok fazla sayıda renk kullanımından kaçınılmalıdır.

- Kullanılan renkler estetik bir bütün oluşturmalıdır,

- Dikkati dağıtmaması için mümkün olduğunca sade olmalıdır,

- Renkler gerçek yaşamdakine uygun olarak kullanılmalıdır (Yanpar, 2009: 152-153).

\section{Öğretim Materyallerinde Görsel Tasarım Illkeleri}

Öğretim materyalinin ilgi çekici ve etkili olabilmesi için gerekli olan bazı tasarım ilkeleri mevcuttur. Tasarlanacak materyallerin öğretimde hedeflenen başarıya ulaşmaya katkı sağlaması için bu ilkeler dikkate alınmalıdır (Örten ve diğer., 2009: 81-83). Bu tasarım ilkeleri bütünlük, denge, vurgu, hizalama ve yakınlıktır.

Bütünlük: Materyaller, verilmek istenilen mesajla ilgili olmayan öğeler barındırmamalıdır. Bütünlüğü oluşturabilmek için materyal öğelerinden (çizgi, şekil, renk vb.) yararlanılır (Örten ve diğerleri, 2009: 81). Görseli anlamayı ve yorumlamay1 kolaylaştıran, bir görseli meydana getiren öğelerin bir bütün olarak görünmesini sağlayan, öğeler arasındaki ilişki olarak tanımlanır. Görselde bütünlük, öğeleri üst üste bindirerek, oklar gibi işaretler ya da çizgi, şekil, renk, çerçeve gibi görsel araçlar kullanarak da sağlanabilir (Yalın, 2009: 114). 
Bütünlük, görsel öğeler ve görsel öğelerin işlevleri arasındaki ilişki ile oluşur. Her görsel unsur, mesaj iletmedeki işlevi göz önüne alınarak yerleştirilmelidir. Yararı olmayan hiçbir unsur (yazı, resim, şekil gibi) materyalde yer almamalıdır (Yanpar, 2009: 154).

Denge: Denge, simetrik ve asimetrik olmak üzere ikiye ayrılır. Denge; biçim, çizgi, yön, açık-koyu zıtlığı, ölçü, aralık, doku, renk ile sağlanır (Ceyhan ve Yiğit, 2003: 90). Denge, öğelerin ağırlıklarının yatay ve dikey eksende her iki tarafa da eşit dağıtılması ile gerçekleştirilir (Örten ve diğerleri, 2009: 82). Merkezden ikiye bölünen tasarımda öğelerin simetrik yerleşmesi durumunda statik bir denge gözlenir. Asimetrik, yani dengenin olmadığı durumlarda ise öğelerin bir tarafa yığılmış olduğu gözlenir (Yalın, 2009: 115).

Vurgu: Bazen materyalde yer alan görselin en can alıcı noktasına dikkat çekip ilgi odağı haline getirilmek istenebilir. Vurgu yapmak için yön araçları, daha parlak renkler, zemin ile zit (kontrast) renkler kullanılabileceği gibi odaklanılacak öğe diğer öğelerden daha büyük yapılabilir, diğerlerinden farklı bir şekil kullanılabilir veya vurgulanacak öğe diğer öğelerin çakıştığı yere yerleştirilebilir (Örten ve diğerleri, 2009: 82). Belirli bir öğeyi dikkat ve ilgi odağı haline getirmek için oklar gibi yön gösteren araçlar kullanmak, daha parlak bir renk kullanmak, daha büyük yapmak, vurgulanmak istenilenin renk ile zeminin rengi arasında zıtlık meydana getirmek, diğer şekillerden daha farklı bir şekil kullanmak, vurgulanacak olan öğeyi diğer öğelerin kesiştiği bir yere yerleştirmek gibi değişik teknikler kullanılabilir (Yalın, 2009: 116).

Hizalama: Hizalama, görsel materyallerin daha kolay anlaşılmasında etkilidir. Ayrıca öğeler arasındaki ilişkilerin daha kolay kavranmasında da önemlidir. Bunların yanı sıra tüm öğelerin materyale göre hizalanmasına da dikkat edilmelidir (Örten ve diğerleri, 2009: 82). İnsanlar dikey ya da yatay olarak hizalanan unsurları karışıklık içerisinde olanlara göre daha rahat algılarlar, kolay öğrenir ve hatırlarlar (Yalın, 2009: 117).

Yakınlık: Bir görselde birbirine yakın öğeler birbirleriyle ilişkili; uzak öğeler ise ilişkisiz olarak alg1lanır (Yalın, 2009: 118). Öğrenciler materyalde yer alan görsellerin birbiriyle ilişkisini yakınlık derecesine göre anlamlandırırlar. Birbiriyle ilişkili olan öğeleri yakın; ilişkisiz olanlarıysa uzak olarak belirlemek mümkündür (Örten ve diğerleri, 2009: 83).

\section{Amaç}

Araştırmanın amacı, Sosyal Bilgiler dersinin kazanımlarına yönelik materyal oluşturularak çizgi romanlarda bulunması gereken özellikleri belirlemek ve oluşturulan materyallerin uygun öğretim yöntem ve tekniklerini desteklemesine ilişkin öneriler getirmektir. Bunun yanında araştırmacılar ilerleyen süreçte çalışmayı deneysel olarak irdelemeyi hedeflemektedir.

$\mathrm{Bu}$ kapsamda öğretim materyali olarak çizgi romanların nasıl oluşturulacağı temellendirilecek, ilköğretim 6. sınıf Sosyal Bilgiler dersinin ilk ünitesi olan "Sosyal Bilgiler Öğreniyorum" ünitesine yönelik; kazanımlara uygun, öğretim materyalleri geliştirme kriterlerini karşılayan çizgi romanlar oluşturulacak ve oluşturulan çizgi romanların çağdaş öğretim yöntem ve teknikleri bakımından kullanımına ilişkin öneriler belirtilecektir.

Sosyal Bilgiler dersinin öğretimde farklı yöntem, teknik ve araç kullanmanın gerekliliği ve çizgi romanların da bu kapsamda kullanılmaya ve oluşturmaya uygun olması bu çalışmanın yapılmasının en önemli nedenlerinden birisidir.

$\mathrm{Bu}$ araştırmanın;

- Çağdaş öğretim yöntem ve tekniklerini destekleyici öğretim materyali olarak oluşturulacak çizgi romanların nasıl oluşturulabileceğine ilişkin kaynak olması,

- Sosyal Bilgiler ders kitaplarında bulunan ünite kazanımlarına dair çizgi romanların oluşturulmasına katkı sağlaması,

- Sosyal Bilgiler öğretimi için oluşturulan çizgi romanların hangi öğretim yöntem ve tekniklerini destekleyebileceğine ilişkin öneriler getirmesi, 
- Araştırma sonunda elde edilen bulguların, konuyla ilgili kişi ve kurumlara katkı sağlaması beklenmektedir.

Araştırmanın problem cümlesi "Sosyal Bilgiler öğretimine yönelik, çağdaş öğretim yöntem ve tekniklerini destekleyebilecek, bir öğretim materyali olarak çizgi romanlar nasıl oluşturulabilir?" şeklinde belirlenmiştir.

Alt problemler;

- Sosyal Bilgiler öğretimi için oluşturulacak çizgi romanlarda hikâye nasıl olmalıdır ve nasıl oluşturulabilir?

- Sosyal Bilgiler öğretimi için oluşturulacak çizgi romanlarda görseller nasıl olmalıdır ve nasıl oluşturulabilir?

- Sosyal Bilgiler öğretimi için oluşturulacak çizgi romanlarda dil ve anlatım nasıl olmalıdır?

- Bu şekilde oluşturulacak çizgi romanlar hangi öğretim yöntem ve tekniklerinin kullanılmasına uygundur? Şeklindedir.

\section{Metodoloji}

Bu bölümde araştırmanın evreni ve örneklemi, veri toplama yöntemleri, veri toplanması ve analiziyle ilgili açıklamalar yer almaktadır.

\section{Araștırma Evreni ve Örneklemi}

Araştırmanın evrenini 6. Sınıf Sosyal Bilgiler ders kitabı oluşturmaktadır. Bu araştırmada örneklemi 6. Sınıf Sosyal Bilgiler ders kitabının ilk ünitesindeki kazanımlar ve araştırmada yararlanılan kaynaklar oluşturmaktadır.

\section{Veri Toplama Yöntemleri}

Araştırmada, paradigmaya dayalı betimsel yöntem kullanılmıştır. Betimsel araştırmalarda ele alınan olaylar ve durumlar ayrıntılı bir şekilde araştırılır, daha önceki durum ve olaylarla ilişkisi incelenerek "ne" oldukları belirlenmeye çalışılır (Karakaya ve Tanrı̈̈̆gen, 2011: 59). Toplanan nitel verilerin derlenmesiyle Sosyal Bilgiler öğretimi amacıyla çizgi romanın nasıl oluşturulması; hangi öğretim yöntem ve teknikleriyle kullanılması gerektiğine ilişkin önerilerde bulunulmuştur.

\section{Verilerin Toplanması ve Analizi}

Araştırma ile ilgili belgesel kaynak derlemesi kapsamında literatür taraması yapılmıştır. Bilindiği üzere belgesel kaynak derlemesi, bir konu hakkında daha önce yazılmış, hazırlanmış, yaratılmış verilerin toplanması ve incelenmesidir (Seydioğlu, 1993: 40). Veri toplama amacıyla 6. Sınıf Sosyal Bilgiler ders kitabı ve materyal geliştirmeye yönelik çeşitli kaynaklar incelenmiştir. Nitel paradigmaya dayalı betimsel model kullanılan bu çalışmada, araştırma sırasında elde edilen veriler, betimleyici ve yorumlayıcı bir teknikle çözümlenmiştir. Süreçte elde edilen veriler üzerinden uygulamalar şekillendirilmiş ve literatür taramasıyla desteklenmiştir.

\section{Bulgular}

$\mathrm{Bu}$ bölüm, "öğretim materyali olarak çizgi roman oluşturma" ve "altıncı sınıf sosyal bilgiler öğreniyorum ünitesinin kazanımları çerçevesinde oluşturulan çizgi romanlar ve kullanılabilecek öğretim yöntem ve teknikleri” başlıklarından oluşmaktadır.

\section{Öğretim Materyali Olarak Çizgi Roman Olușturma}

$\mathrm{Bu}$ başlık altında öğretim materyali olarak çizgi roman geliştirme ele alınarak önce 
hikâyenin nasıl oluşturulacağı; ardından çizimlerin nasıl yapılacağı ortaya konulacaktır.

\section{Hikâye}

Hikâye, ilgi çekicilikten uzak, bilgiyi direk aktaran bir yapı arz ederse öğrenci için yalnızca resimlendirilmekten öteye gidemeyen sıkıcı bir akademik kitap halini alacaktır. Bu bölümde, "Yaratıcı Yazma Süreci" (Temizkan, 2014) ve "Iyi Yazmak Üzerine" (Zinsser, 2014) adlı eserlerden geniş ölçüde yararlanılmıştır.

Çizgi roman senaryosu konu, tretman ve senaryo olmak üzere üç basamaktan oluşmaktadır. Bu kapsamda öğretim materyali olarak oluşturacağımız çizgi romanda üç basamağı en basit haliyle şu şekilde açıklayabiliriz:

1.1. Коnu: Öğretim amaçlı geliştirilecek olan çizgi romanlarda konuyu "kazanım” olarak ele almak mümkündür.

1.2. Tretman: Kazanımın senaryolaştırmaya hazırlandığ 1 , bir kurgu olarak ortaya konduğu bölümdür. Bu bölümde mekân, zaman, karakterler ve olay ya da sorun basit biçimde ele alınır.

1.3. Senaryo: Çizgi romanın çizimden hemen önce yazı boyutunda tamamen tamamlanmış halidir. Karakterlerin görünüş tasvirleri, diyalogları, sayfa düzeni ve karelerin içeriği tam haliyle belirlenir.

\section{2. Örnek bir hikâye çalıșması}

Araştırmanın uygulama boyutunda anlam kazanabilmesi için örnek bir çalışmanın yapılması gereklidir. Söz konusu çerçevede, bu başlık altında örnek çalışmanın çizim altyapısını destekleyen teorik (metin) kısmı yer alacaktır.

2.1. Копи: Yakın Çevresindeki Bir Örnekten Yola Çıkarak Bir Olayın Çok Boyutluluğunu Fark Eder.

2.2. Tretman: Tretman (çizgi romanda anlatılacak olanlar), kahramanlar, olay örgüsü, mekân, zaman ve anlatıcı alt başlıklarından oluşmaktadır.

\section{Kahramanlar:}

- Asıl Kahraman: Ortaokul öğrencisi Soysal,

- Yardimci Kahramanlar: Soysal'in anne ve babası,

- Figüran Karamanlar: Soysal'ın köpeği sayesinde kazandığı yeni arkadaşlar.

Olay Örgüsü: Ebeveynlerinin aldığı bir köpek, Soysal'ın hayatında olumlu ve olumsuz olmak üzere farklı durumlar yaratacak.

Mekân: Soysal'ın odası. Soysal'ın odası haricindeki mekânlar belirsiz bırakılacaktır.

Zaman: Vaka zamanı olarak Soysal'ın köpeksiz ve köpekli olarak içinde bulunduğu durumları anlatan kısa bir süreç.

Anlatıcı: Gözlemci bakış açısı.

Senaryo: Bu başlık altında oluşturulan çizgi-romanın senaryosu aşamalı (kareler şeklinde) olarak anlatılacaktır.

\section{3. Çizgi romanın görselleștirilmesi}

Çizgi roman oluşturma süreci; bilgi, hayal gücü, özgünlük, titizlik ve dikkat isteyen ciddi bir süreçtir. En basit haliyle çizgi roman oluşturma sürecini aşağıdaki gibi izleyebiliriz. 


\subsection{Yeni bir șey yaratmak: kurșun kalemle ilk dokunușlar}

Karakalem çalışması şu sırayı takip edebilir:

- Tretman ya da senaryodan gelen veriler ışığında karelerin boyutu tasarlanır.

- Perspektife karar verilir.

- Varlıklar ilgili yerlere yerleştirilir. İlk çizgiler yalnızca bunların yerlerini belirlemek için kullanılır, detaylandırılmaz.

- Varlıklar kılavuz çizgiler yardımıyla detaylandırılır.

- Varlıkların (olması gerektiğine karar verilen) çizgilerinin üzerinden daha koyu çizgiyle geçilir. Çizimde ana hatlar belirlenir.

\subsection{Yaratılanı ölümsüzleștirmek: mürekkep kullanmak}

Farklı mürekkeplendirme seçeneği olsa da çoğu zaman en kolay olan yöntem fiber uçlu kalemler kullanmaktır. Karakalemle belirlenen çizgilerin üzerinden fiber uçlu çizim kalemleriyle geçilir. İşlemin sonunda kurşun kalem izleri silinir.

\subsection{Dijital ortama aktarmak: tarama süreci}

Çizim sürecinde pek çok engelle karşılaşmak mümkündür. Durum böyle olsa da fiber uçlu kalemlerle çizim sırasında ortaya çıkan kusurlu çizgileri dijital ortamda düzenlemek mümkündür. Dijital ortamın bir diğer faydası ise, boyama ve gölge-1şık aşamalarında sağladığı ekonomikliktir. Tarama sürecinde dikkat edilmesi gereken husus, standart bask1 boyutu olan 300 DPI (Bir inç karedeki nokta sayısı)'yi destekleyecek bir tarama gerçekleştirebilmektir.

\subsection{Dijital ortamda görüntüyü ayarlamak}

Çizimi destekleyebilecek pek çok profesyonel grafik tasarım programı olmasına karşın, bu çalışmada İngilizce dilinde Adobe Photoshop CC 2015 kullanılmıştır.

\section{5. Çizgi romana dijital ortamda renk katmak}

Gerektiği yere göre: "Paint Bucket Tool”, "Gradient Tool”, "Brush Tool”, "Pencil Tool” gibi araçlarla farklı doku ve tonlarda renk katmak mümkündür. Adobe Photoshop CC 2015 'te çok farklı firçalar mevcuttur.

\subsection{Gölgelendirme ve ıșıklandırma}

Gölgelendirme ve 1şıklandırma yine boyama araçları kullanılarak yapılabileceği gibi, yeni Layer'ler açarak ışık ve gölge tonlarının verilmesi sonrası "Vector Mask" kullanımıyla da sağlanabilir.

\subsection{Dijital ortamda konușma balonlarını yerleștirme}

Konuşma balonuna siyah çerçevesini vermek için konuşma balonunun olduğu Layer sekmesine çift tıklanır, "Drop Shadow" seçeneği ile dışına gölge vermek suretiyle çizgi oluşturulabilir. Bunun için Drop Shadow'un özellikleri "Opacity 100", "Distance 0", "Spread 100", "Size" ise tercihe göre belirlenir. Standart 300 DPI bask1 alınacak olan A4 Boyutu sayfalarda konuşma balonlarına koyulacak çizgi için 6 birimlik Size idealdir.

\subsection{Metni Yerleștirme}

Burada esas olan öğretim materyallerinde yazı öğelerinde olması gereken kıstasları karşılayacak bir çalışma yapmaktır. Bu çalışmada "Calibri” yazı tipi seçilmiş olup, boyut 14 punto olarak belirlenmiştir. 


\subsection{Baskıya Hazır Hale Getirme}

Boyut daha önce de belirtildiği gibi 300 DPI olmalıdır. Çalışma tamamlandı̆̆ında kaydetme seçeneklerinden JPEG, PNG gibi formatlarla kayıt gerçekleştirilebilir

Altıncı Sınıf Sosyal Bilgiler Öğreniyorum Ünitesinin Kazanımları Çerçevesinde Olușturulan Çizgi Romanlar ve Kullanılabilecek Öğretim Yöntem ve Teknikleri

$\mathrm{Bu}$ bölümde araştırmacı tarafından kazanımlara ve öğretim materyali olma durumlarına uygun olarak geliştirilen çizgi romanlara yer verilmiştir. Standartlık arz etmesi için çizgi romanlar ikişer sayfa olarak tasarlanmıştır.

1. "Yakın çevresindeki bir örnekten yola çıkarak bir olayın çok boyutluluğunu fark eder" kazanımı çerçevesinde olușturulan çizgi roman

6. sınıf 1. ünite 1. kazanıma göre oluşturulan bu çizgi roman, eğitsel oyun kategorisi içerisinde yer alan arkası yarın tekniğine ve örnek olay yöntemi içerisindeki beyin firtınası tekniğine göre tasarlanmıştır.

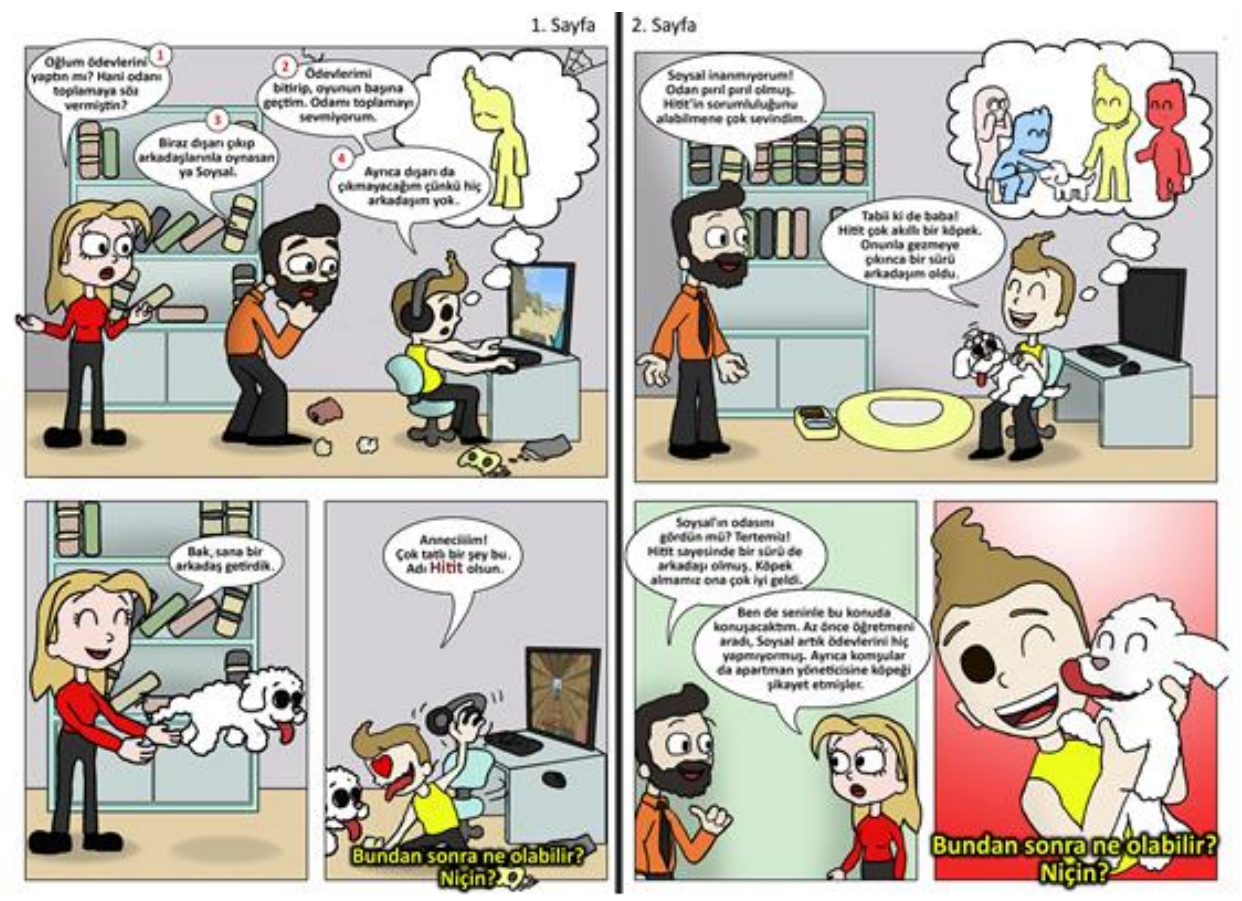

Şekil 1. 6. sınıf. 1. ünite 1. kazanım çerçevesinde oluşturulan çizgi roman.

2. "Olgu ve görüşü ayırt eder kazanımı" kazanımı çerçevesinde olușturulan çizgi roman

6. sınıf 1. ünite 2. kazanıma göre oluşturulan bu çizgi roman, örnek olay yöntemi içerisinde yer alan karar verme tekniğine göre tasarlanmıştır. 


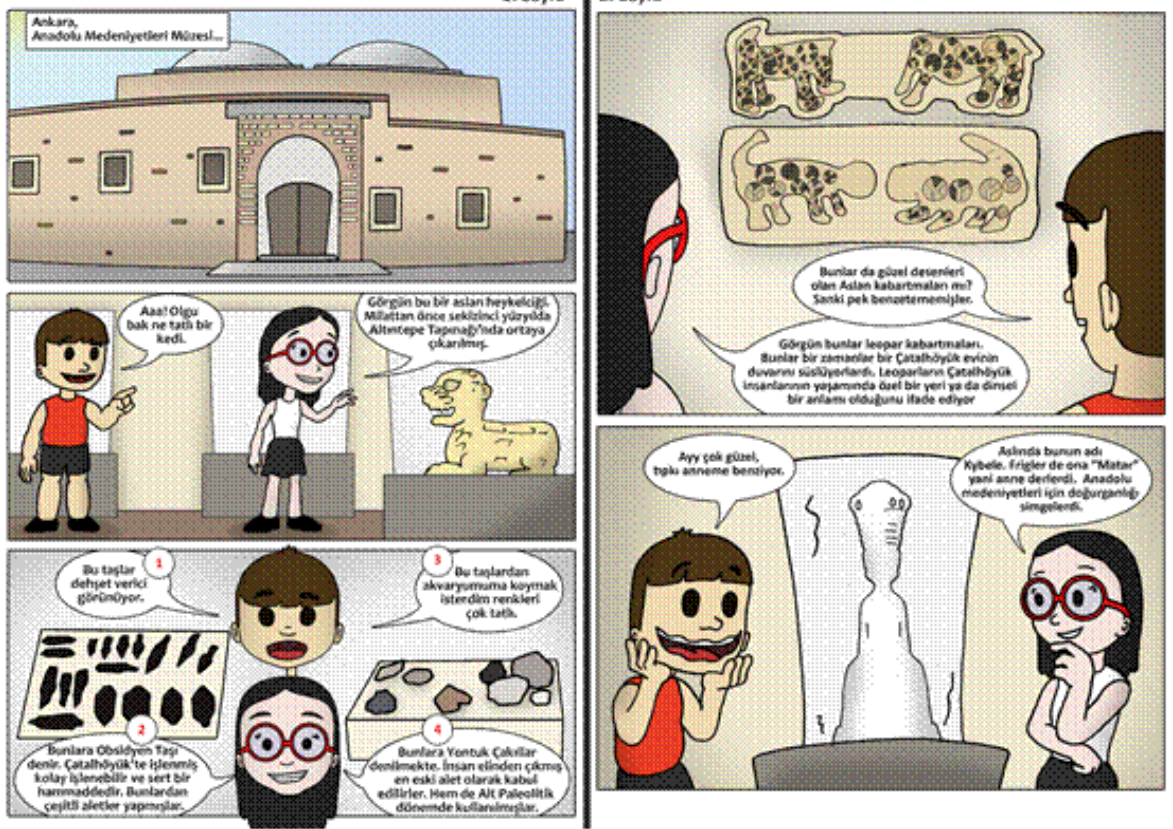

Şekil 2. 6. Sınıf. 1. ünite 2. kazanım çerçevesinde oluşturulan çizgi roman.

3. "Bilimsel araștırma basamaklarını kullanarak araștırma yapar" kazanımı çerçevesinde oluşturulan çizgi roman

6. sınıf 1. ünite 3. kazanıma göre oluşturulan bu çizgi roman, problem çözme yöntemine göre tasarlanmıştır. Amaç öğrenciyi araştırma yapmaya sevk etmektir.

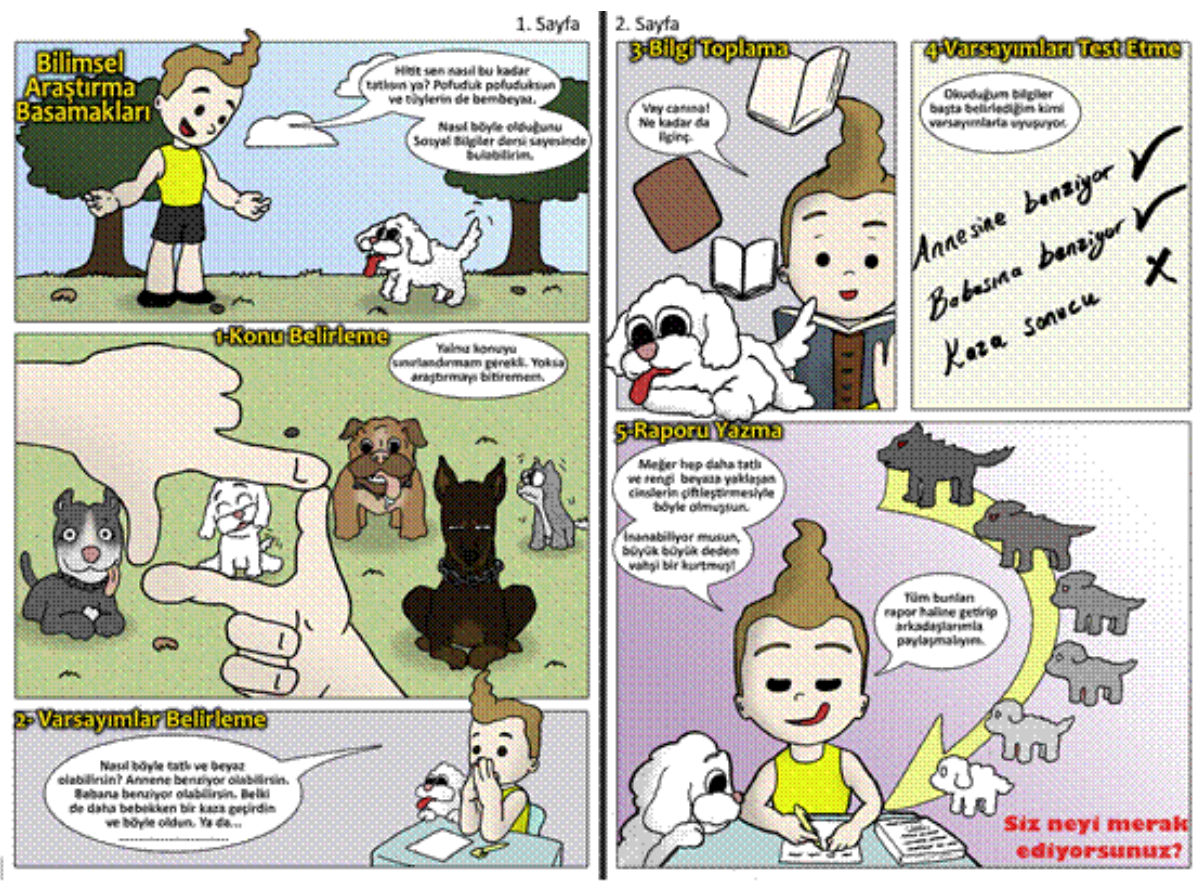

Şekil 3. 6. Sınıf. 1. ünite 3. kazanım çerçevesinde oluşturulan çizgi roman. 
4. "Bir soruna getirilen çözümlerin hak, sorumluluk ve özgürlükler temelinde olması gerektiğini savunur" kazanımı çerçevesinde olușturulan çizgi roman

6. sınıf 1. ünite 4. kazanıma göre oluşturulan bu çizgi roman, soru-cevap tekniğine göre tasarlanmıştır.
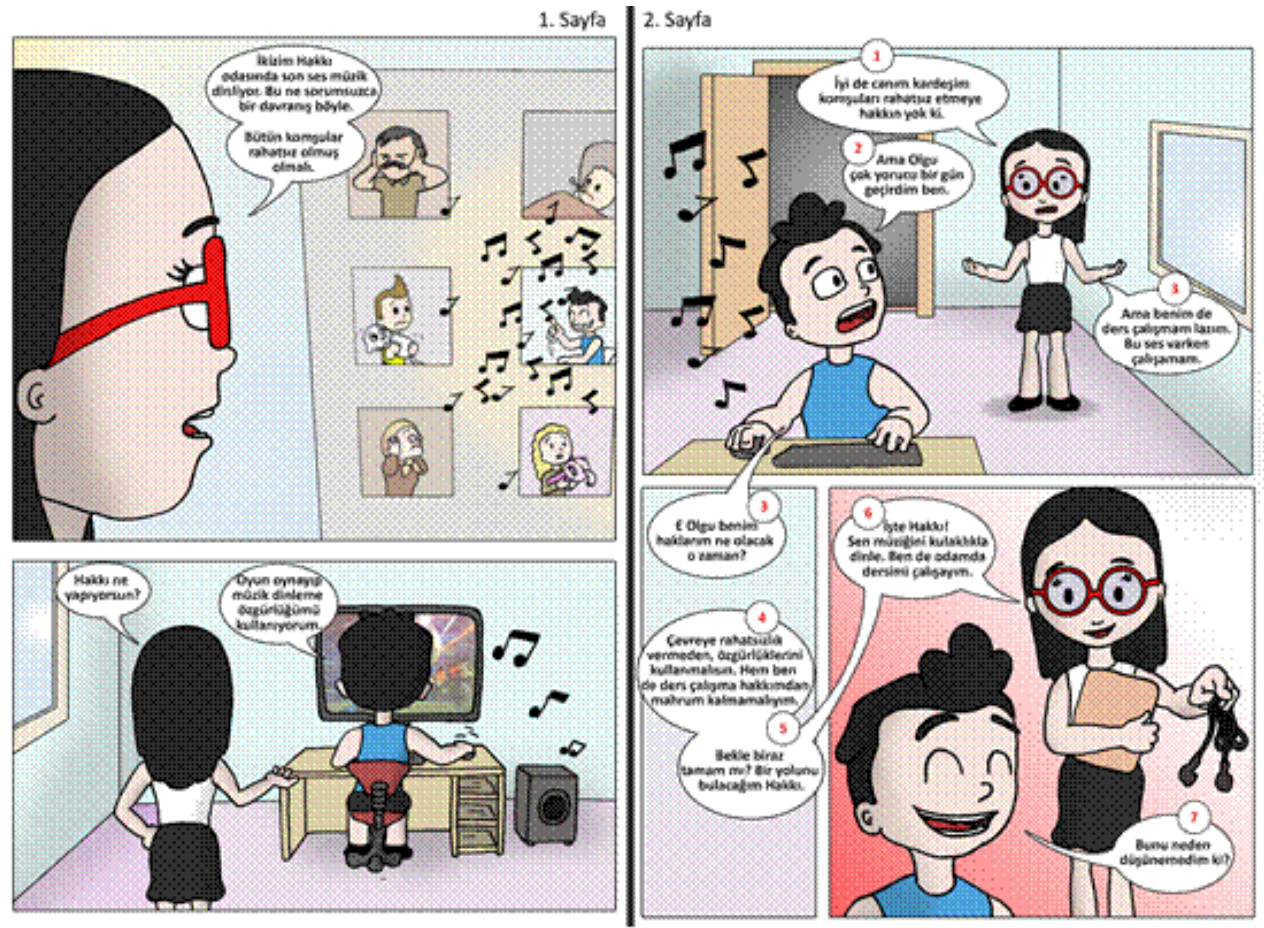

Şekil 4. 6. Sınıf. 1. ünite 4. kazanım çerçevesinde oluşturulan çizgi roman. 
5. “Sosyal bilgilerin, Türkiye Cumhuriyeti'nin etkin bir vatandașı olarak gelișimine katkısını fark eder" kazanımı çerçevesinde olușturulan çizgi roman

6. sınıf 1. ünite 5. kazanıma göre oluşturulan bu çizgi roman, eğitsel oyun kategorisi içerisindeki rol yapma/rol oynama tekniğine göre tasarlanmıştır.
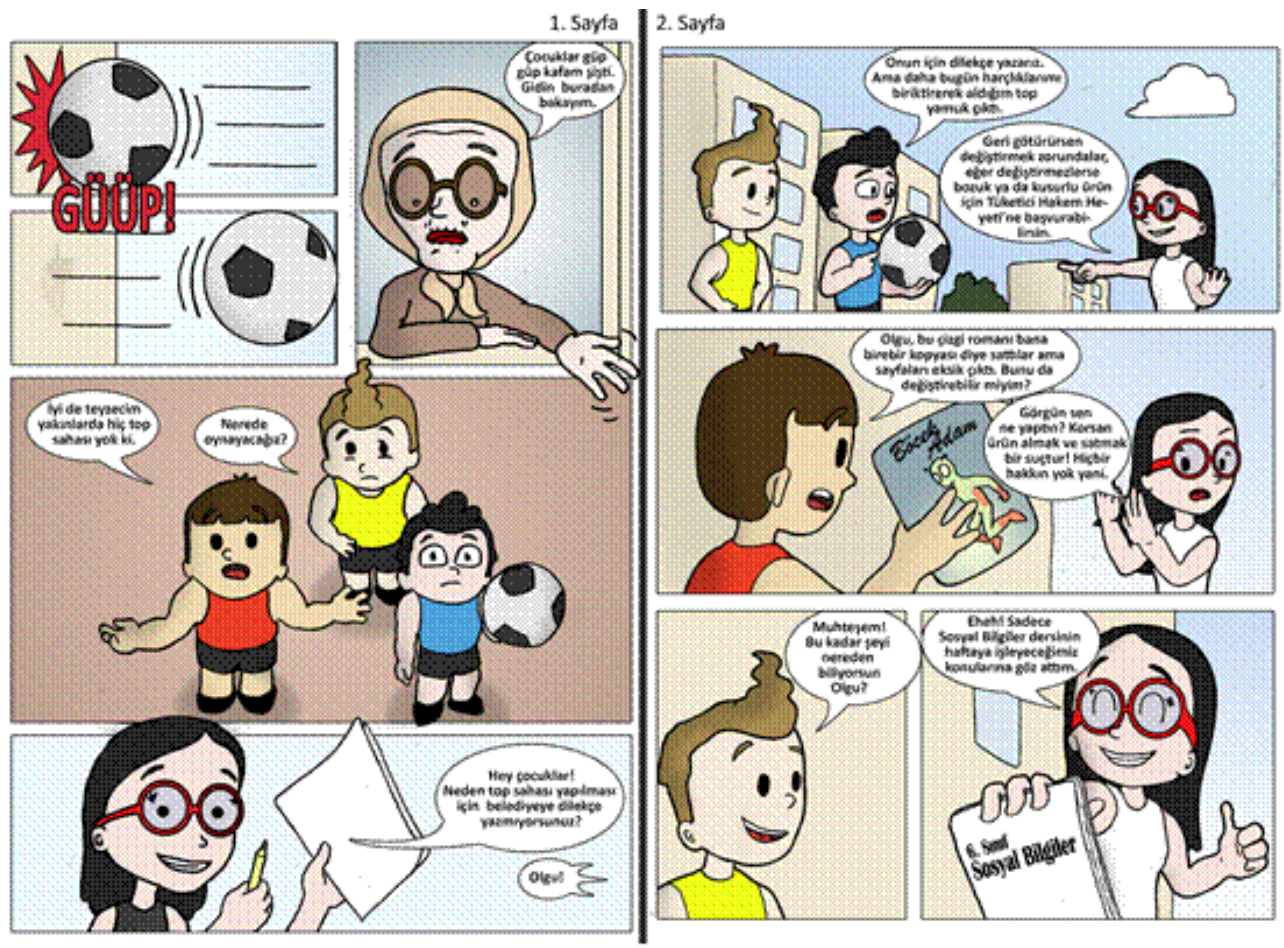

Şekil 5. 6. Sınıf. 1. ünite 5. kazanım çerçevesinde oluşturulan çizgi roman. 
6. “Atatürk'ün ülkemizde sosyal bilimlerin geliștirilmesi için yaptığı uygulamalara örnekler verir" kazanımı çerçevesinde oluşturulan çizgi roman

6. sınıf 1. ünite 6. kazanıma göre oluşturulan bu çizgi roman, tartışma yöntemi içerisindeki çember tekniğine göre tasarlanmıştır.
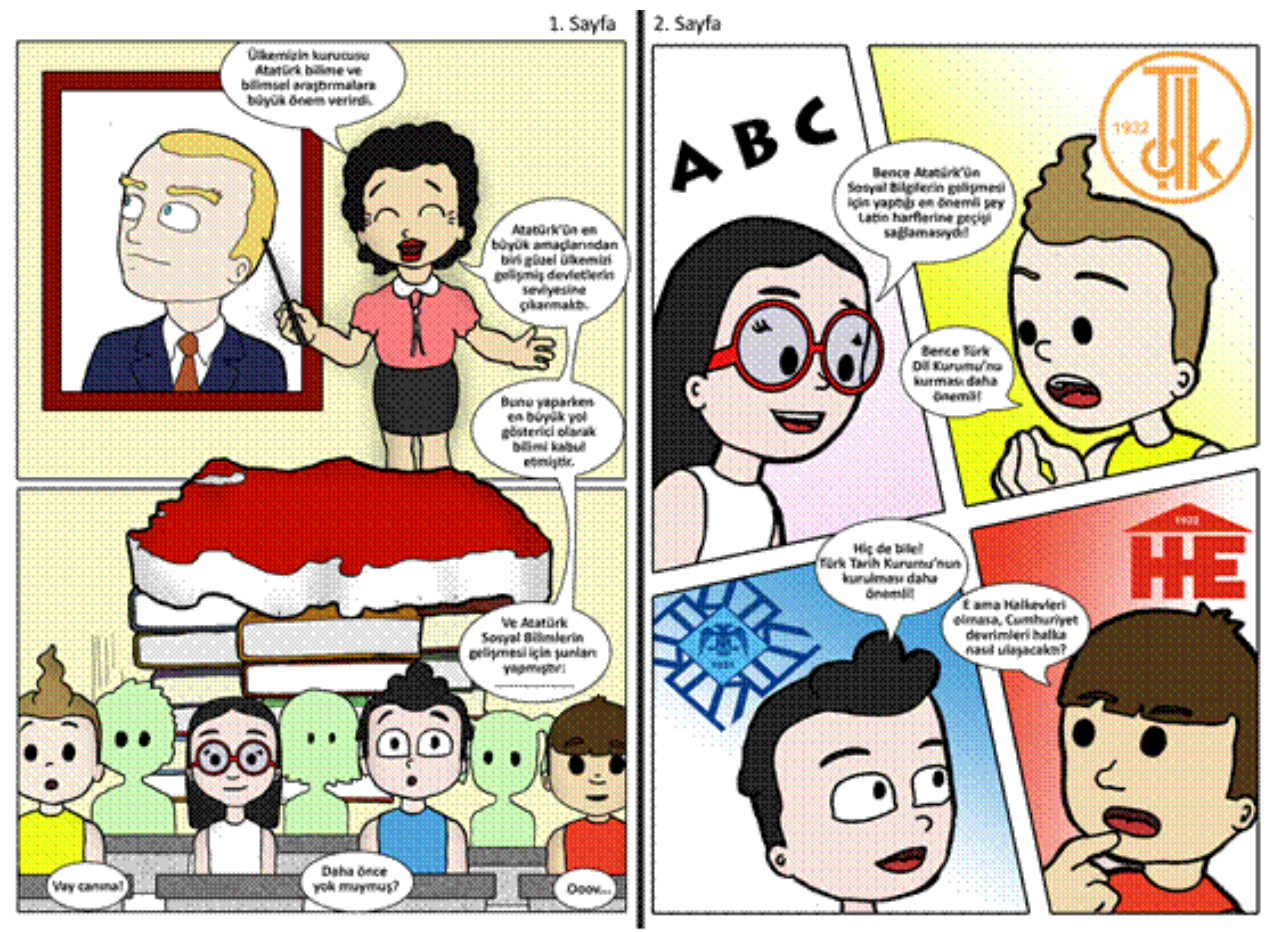

Şekil 6. 6. sınıf. 1. ünite 6. kazanım çerçevesinde oluşturulan çizgi roman.

\section{Tartıșma ve Sonuç}

Eğitim-öğretim sürecinde çizgi roman kullanımı öğrenci başarılarını olumlu yönde etkilemektedir. Nitekim bazı araştırmacılar tarafından hazırlanan çalışmalarda çizgi romanla öğretimin öğrencilerin başarısını olumlu yönde etkilediği sonucuna varılmıştır (Hosler ve Boomer, 2011; Griva, Alevriadou ve Semoglou; 2012; Kılıçkaya ve Krajka, 2012; Botzakis, 2013; Efecioğlu, 2013; Orçan, 2013; Topkaya, 2014; Gavigan ve Albright, 2015; Richter, Rendings ve Maminirina, 2015; İlhan, 2016). Çizgi romanların Sosyal Bilgiler dersi öğretiminde kullanılmasının öğrencilerin başarılarını olumlu yönde etkilediği de bilinen bir gerçektir (Yılmaz, 2008; Altun, 2014; Dönmez ve Yeşilbursa, 2014; İlhan, 2016; Ünal ve Demirkaya, 2019).

Söz konusu çalışmalardan hareketle 6. Sınıf Sosyal Bilgiler dersi kazanımları çerçevesinde tarafımızca bir öğretim materyali olarak çizgi roman oluşturulmuştur. Başka bir deyişle bu çalışma, öğretim materyali olarak çizgi roman geliştirme sürecini ortaya koyması ve doğrudan kazanımlar için çizgi roman oluşturmaya yönelik bir araştırma olması bakımından orijinallik arz etmektedir. Çizgi roman oluşturma sürecinde yalnızca öğretim materyali geliştirme ilkeleri dikkate alınmamış; çağdaş öğretim yöntem ve teknikleri de işe koşulmuştur. Söz konusu çizgi romanlar seçtiğimiz öğretim yöntem ve tekniklerine uygun olarak tarafımızca geliştirilmiştir. Bu çalışmanın ilerleyen süreçte deneysel olarak yürütülmesi hedeflerimiz arasındadır. 
Araştırma kapsamında elde edilen bulgulara dayalı sonuçlar aşağıdaki şekilde özetlenebilir.

Öğretim amaçlı kullanılacak çizgi romanları oluşturmak ciddi bir bilgi birikimi ve yaratıcılık isteyen bir süreçtir. Sosyal Bilgiler öğretimine yönelik oluşturulacak çizgi romanların, çizgi roman unsurlarının öğretim açısından ele alınarak oluşturulması gerekmektedir. Doğru adımlar takip edilerek Sosyal Bilgiler öğretimi için çizgi romanlar oluşturulabilir. Sosyal Bilgiler dersi öğretiminde çizgi roman kullanımı öğrenci başarısı üzerinde olumlu yönde etkili olsa da öğretim sırasında kimi hususlara dikkat etmek gerekmektedir. Nitekim kullanılacak olan çizgi romanların konuya, öğrenciye ve çağdaş öğretim yöntem-tekniklerine uygun olmasına dikkat edilmelidir. Çizgi romanlar çağdaş öğretim yöntem ve tekniklerini destekleme konusunda son derece kuvvetli öğretim materyalleri olabilmektedir. Oluşturulan çizgi romanların öğrencilerin derse yönelik ilgi ve tutumlarını olumlu yönde etkilemesi beklenmektedir. Oluşturulan çizgi romanların konu alanında başarıyı artırması beklenmektedir.

\section{Öneriler}

Araştırma bulguları doğrultusunda Sosyal Bilgiler dersinde çizgi roman oluşturulmasına ve Sosyal Bilgiler dersinde uygulanmasına yönelik öneriler aşağıdaki gibidir.

\subsection{Sosyal Bilgiler Dersinde Çizgi Roman Olușturulmasına Yönelik Öneriler}

Sosyal Bilgiler dersi kapsamında bir öğretim materyali olarak çizgi romanlar oluşturulurken aşağıdaki hususlara dikkat edilebilir:

- Pratik veya profesyonel destek ile sosyal bilgiler öğretmenleri öğretim amaçlı (kendi) çizgi romanlarını oluşturabilirler,

- Sosyal Bilgiler öğretimi amaçlı çizgi roman oluşturmada profesyonel yazar ve çizerlerden destek alınabilir,

- Çizgi roman oluşturulurken, Sosyal Bilgiler Öğretim Programı göz önünde bulundurulmalıdır,

- Milli Eğitim Bakanlığı Ders Kitapları ve Eğitim Araçları Yönetmeliğinde belirlenen ders kitabı ölçütleri göz önünde bulundurulmalıdır,

- Çizgi romana kaynaklık eden kazanımlar dikkatle incelenmelidir,

- Çizgi romanlar yalnızca okunacak olan bir materyal olarak değil, çağdaş öğretim yöntem ve tekniklerini destekleyecek bir yapıda olmalıdır,

- Çizgi romanlar oluşturulurken materyal tasarımına ilişkin görsel tasarım ilkeleri dikkate alınmalıdır,

- Çizgi romanlar geliştirilirken öğretim materyali kapsamında yazı öğelerine ilişkin ilkeler dikkate alınmalıdır,

- Çizgi roman oluşturmada öğrencilerin düzeyi göz önüne alınmalı, şiddet, argo, cinsellik içerek öğelere yer verilmemelidir,

- Çizgi romanlarda etnosantrik unsurlar yer almamalıdir,

- Çizgi romanlarda konuyu odak noktasından uzaklaştırmayacak kadar mizahi unsurlara yer verilmelidir,

- Oluşturulacak olan çizgi romanlarda gereksiz detaylara yer verilmemeli, mesaja yoğunlaşılmalıdır,

- Çizgi romanlarda bir evren oluşturulmalı, oluşturulan evren çok karışık bir yap1 arz etmemelidir, öğrenciler bu evrende olan bitenleri ilk görüşte anlayabilmelidir,

- "Kendi Maceranı Kendin Seç" türünde öğrenciye sınırlı da olsa senaryoya etki etme firsatı yaratacak çizgi romanlar oluşturulabilir, 
- Sosyal bilgiler öğretimi için çizgi roman oluşturma sürecine öğrenciler de dâhil edilebilir.

\section{2. Çizgi Romanın Sosyal Bilgiler Dersinde Uygulanmasına Yönelik Öneriler}

Sosyal Bilgiler dersinde çizgi romanların uygulanmasına yönelik öneriler aşağıdaki gibidir:

- Çizgi romanlar derste okuma aracı olarak dikte edilmemeli, çağdaş öğretim yöntem ve tekniklerinin bir parçası olarak verilmelidir,

- Çizgi romanlar birden fazla çağdaş öğretim yöntem ve tekniğiyle verilebilir,

- Öğrencilere deneyimleyerek öğrenme firsatı verilmelidir,

- Öğrencilerin kişisel yorumlarına saygı duyulmalıdır, nitekim her insanın dünyayı algılayış biçimi farklıdır,

- Öğrenci sürece aktif olarak dâhil edilmelidir,

- Grup çalışması teşvik edilmelidir,

- Süreç güncel öğretim yöntem tekniklerine uygun değerlendirmeyle tamamlanmalidır.

\section{Araştırmanın Sınırlılıkları ve Gelecek Araștırmalar}

$\mathrm{Bu}$ araştırma kapsamında oluşturulan çizgi romanlar 2017-2018 eğitim-öğretim y1lı Milli Eğitim Bakanlığı 6. Sınıf Sosyal Bilgiler ders kitabında yer alan "Sosyal Bilgiler Öğreniyorum" ünitesinin kazanımlarıyla sınırlıdır. Öğretim yöntem ve teknikleri kazanımlara göre araştırmacılar tarafından seçilmiştir.

\section{Yazar Katkıları}

Bu çalışma yüksek lisans tez (Oluşturma ve Uygulama Açısından Sosyal Bilgiler Öğretiminde Bir Öğretim Materyali Olarak Çizgi Roman Kullanımı) çalışmasından üretilmiştir. Çalışma yazarları yüksek lisans öğrencisi ve danışmanını içermektedir. Çalışmanın her aşamasında her iki yazar katkı sağlamıştır. Tüm yazarlar makalenin yayınlanmış halini okuyup kabul etmişlerdir.

\section{Yayın Etiği}

Araştırma ve Yayın Etiği'ne uyuldu.

\section{ORCID}

Ali Ekber GÜLERSOY (1) https://orcid.org/0000-0003-0338-1366

Berkay TÜRKAL (D) https://orcid.org/0000-0002-3470-2735

\section{Kaynakça}

Akdağ, H., Turan, R., Sünbül, A.M. ve Akdağ, H. (2009). Sosyal bilgilerin tanımı, amac1, önemi ve Türkiye'deki yeri. R. Turan, A.M. Sünbül ve H. Akdağ (Editör), Sosyal Bilgiler Öğretiminde Yeni Yaklaşımlar-I (1-24) içinde. Ankara: Pegem Akademi Yayınları.

Alpin, H. (2006). Çizgi Roman Ansiklopedisi. İstanbul: İnkilap Kitabevi.

Alsaç, Ü. (1994). Türkiye'de Karikatür, Çizgi Roman ve Çizgi Film. İstanbul: İletişim Yayınları.

Ardasheva, Y., Bowden, J., Morrison, J., \& Tretter, T. (2015). Using comics and 1llustrated trade books to support science learning in first year englishlanguage learners. Science Scope, 2015(1), $39-48$. 
Altun, A. (2014). İlkokul ve ortaokul öğrencilerinin tarih kavramına ilişkin algılarının yörüngesi. Kuram ve Uygulamada Eğitim Bilimleri, 14(6), 2305-2326.

Berson, I. \& Berson, M. (2011). Integrating literature and the social studies with google lit trips. Social Education, 75(2), 111-113.

Botzakis, S. (2013). Why I teach comics in higher education. Knowledge Quest, 41(3), 68-70.

Cantek, L. (2014). Türkiye'de Çizgi Roman. İstanbul: İletişim Yayınları.

Carr, P. (1958). Can comic books be used in education? Education, 79, 57-61.

Ceran, K. ve Cantek, L. (2004). Çizgi Roman Nedir? Çizgili Hayat Kılavuzu. İstanbul: İletişim Yayınları.

Ceyhan, E. ve Yiğit, B. (2003). Konu Alanı Ders Kitabı Incelemesi. Ankara: Anı Yayıncılık.

Cirigliano, M. M. (2012). Exploring the attitudes of students using an edutainment graphic novel as a supplement to learning in the classroom. Science Educator, 21(1), 29.

Çapar, T. ve Gümüş, N. (2016). Coğrafya öğretiminde sketch-up modelleri kullanımının öğrencilerin derse yönelik tutumlarına etkisi. Buca Eğitim Fakültesi Dergisi, (42), 74-83.

Çelikkaya, T. (2013). Sosyal bilgiler öğretiminde araç-gereç ve materyal kullanımının önemi. Sosyal Bilgiler Öğretiminde Ĕ̆itim Teknolojileri ve Materyal Tasarımı (39-68) içinde. R. Sever ve E. Koçoğlu (Editör). Ankara: Pegem Akademi.

Çetin, Y. (2010). Milli folklore. Okutan Çizgiler. 85, 193-198.

Demir, S. B. ve Akengin, H. (2011). Hikâyelerle Sosyal Bilgiler Öğretimi. Ankara: Pegem Akademi.

Dönmez, C. ve Yeşilbursa, C. C. (2014). Ortaokul öğrencilerinin tarih algısı. Gazi Üniversitesi Gazi Ĕgitim Fakültesi Dergisi, 34(3), 415-436.

Duverger, M. (1999). Metodoloji Açısından Sosyal Bilimlere Girişs (Beşinci Basım) (Çev. Ünsal Oskay). Ankara: Bilgi Yayınevi.

Efecioğlu, E. (2013). Çizgi romanın İngilizce yabancı dil olarak ögretiminde rolü. Yayımlanmamış yüksek lisans tezi. Hacettepe Üniversitesi, Sosyal Bilimler Enstitüsü, Ankara.

Erden, M. (1997). Sosyal Bilgiler Öğretimi. İstanbul: Alkım Yayınevi.

Gavigan, K. \& Albright, K. (2015). Writing from behind the fence. Journal of Adolescent \& Adult Literacy, 59(1), 41-50.

Griva, E., Alevriadou, A., \& Semoglou, K. (2012). Reading preferences and strategies employed by primary school students: Gender, socio-cognitive and citizenship issues. International Education Studies, 5(2), 24-35.

Güneş, F. (2002). Ders Kitaplarının Incelenmesi. Ankara: Ocak Yayınları.

Hosler, J. \& Boomer, K. B. (2011). Are comic books an effective way to engage nonmajors in learning and appreciating science? CBE-Life Sciences Education, 10(3), 309-317.

İlhan, G.O. (2016). Sosyal bilgilerde çizgi romanların kullanımı. Yayınlanmamış doktora tezi. Afyon Kocatepe Üniversitesi, Sosyal Bilimler Enstitüsü, Afyon.

İşler, A. (2003). Yazılı ders materyallerinde illüstrasyon kullanımının yeri ve önemi. Milli Ĕgitim Dergisi, 157, 55-63.

Karakaya, İ. ve Tanrı̈ğen, A. (2011). Bilimsel Araştırma Yöntemleri. Ankara: Anı Yayıncılık.

Kilıçkaya, F. \& Krajka, J. (2012). Can the use of web-based comic strip creation tool facilitate EFL learners' grammar and sentence writing? British Journal of Educational Technology, 43(6), 161-165.

Kısakürek, A. (1989). Sosyal Bilgiler Öğretimi. Eskişehir: Anadolu Üniversitesi Açıköğretim Fakültesi Yayınları.

Koşar. E, ve Çiğdem, H. (2003). Öğretim Teknolojileri ve Materyal Geliştirme. Ankara: Pegem Akademi.

Orçan, A. (2013). Çizgi-roman tekniği ile geliştirilen bilim-kurgu hikâyelerinin öğrencilerin yaratıcı düşünme becerilerinin ve fiziğe ilişkin tutumlarının gelişimine etkisi. Yayınlanmamış yüksek Lisans Tezi. Gazi Üniversitesi, Eğitim Bilimleri Enstitüsü, Ankara.

Örten H., Keskin, Y. Ekici, Ö. Sever, R. ve Koçoğlu, E. (2013). Sosyal bilgiler dersinde materyal hazırlamanın temelleri. R. Sever ve E. Koçoğlu (Editör), Sosyal Bilgiler Öğretiminde Ĕ̌itim Teknolojileri ve Materyal Tasarımı (69-88) içinde. Ankara: Pegem Akademi.

Özşen, M. E., Sayın, G. ve Aygün Cengiz, S. (2004). Çizgi roman özel bölümü, süper kahramanlar: kostümün altında yatan ideoloji. Folklor/Edebiyat Dergisi, 39(3), 74-110.

Öztürk, C. (2012). Sosyal bilgiler: toplumsal yaşama disiplinlerarası bir bakış. C. Öztürk (Editör), Sosyal Bilgiler Öğretimi (1-31) içinde. Ankara: Pegem Akademi Yayınları.

Richter, T., Rendigs, A., \& Maminirina, C. P. (2015). Conservation messages in speech bubblesevaluation of an environmental education comic distributed in elementary schools in 
madagascar. Sustainability, 7(7), 8855-8880.

Sağlamer, E. (1983). İlkokulda Sosyal Bilgiler Öğretimi. Ankara: Tekışık Matbaası.

Savaş, B. (2007). Öğretim yöntemleri. M. Arslan (Editör), Öğretim Ilke ve Yöntemleri (153-170) içinde. Ankara: Anı Yayıncılık.

Semenderoğlu, A. ve Gülersoy, A. E. (2005). İdeal sosyal bilgiler programı arayışında yeni sosyal bilgiler ögretim programlarının değerlendirilmesi. Van Yüzüncü Yıl Üniversitesi’nde düzenlenen II. Sosyal Bilimler Eğitimi Kongresi'nde sunulmuş bildiri, Van Yüzüncü Yı1 Üniversitesi, Van.

Seydioğlu, H. (1993). Bilimsel Araştırma ve Yazma El Kitabı. İstanbul: Güzem Yayınları.

Somuncu, S. (2010). İlköğretim Türkçe ders kitabındaki edebi metinlerin içerdiği evrensel değerlere ve metin seçimine ilişkin bazı tespitler. Selçuk Üniversitesi Edebiyat Fakültesi Dergisi, 24, 193-219.

Sönmez, V. (1999). Sosyal Bilgiler Öğretimi ve Öğretmen Kılavuzu. İstanbul: MEB Yayınları.

Tatalovic, M. (2009). Science comics as tools for science education and communication: a brief, exploratory study. Journal of Science Communication (JCOM), 8(4), 1-17.

Tay, B., Turan, R. ve Ulusoy, K. (2010). Sosyal bilgiler öğretiminin dünü bugünü ve yarını. R. Turan ve K. Ulusoy (Editör), Sosyal Bilgilerin Temelleri (229-240) içinde. Ankara: Maya Akademi.

Temizkan, M. (2014). Yaratıcı Yazma Süreci (Hikaye Yazma). Ankara: Pegem Akademi.

Topkaya, Y. (2014). Vatandaşlık ve demokrasi eğitimi dersinde eğitici çizgi roman kullanımının bilişsel ve duyuşsal ögrenmelere etkisi. Yayınlanmamış doktora tezi. Atatürk Üniversitesi, Eğitim Bilimleri Enstitüsü, Erzurum.

Trent, C. \& Kinlaw, R. (1979). Comic books: An effective teaching tool. Journal of Extension, $17(1), 18-23$.

Ünal, O. ve Demirkaya, H. (2019). Eğitici çizgi romanın sosyal bilgiler dersinde kullanılmasına yönelik yarı deneysel bir çalışma. International Journal of Geography and Geography Education (IGGE), 40, 92-108.

Wright, G. (1979). The comic book: a forgotten medium in the classroom. The Reading Teacher, 33(2), 158-161.

Yalın, H. İ. (2009). Öğretim Teknolojileri ve Materyal Geliştirme. Ankara: Nobel Yayıncılık.

Yanpar, T. (2009). Öğretim Teknolojileri ve Materyal Tasarımı. Ankara: Anı Yayıncılık.

Yıldız, R. (2004). Öğretim Teknolojileri ve Materyal Geliştirme. Konya: Atlas Kitabevi.

Yilmaz, K. (2008). A vision of vistory teaching and learning: Thoughts on history education in secondary schools. The University of North Carolina Press, 92(2), 37-46.

Zinsser, W. (2014). İyi Yazmak Üzerine (1. Basım) (Çev. Barış Tanyeri). İstanbul: Altıkırkbeş Yayınlar1. 


\section{Extended Abstract}

\section{Introduction}

Although Social Studies has a lot of different definitions, it is possible to explain forwhat it is with mutual expressions. These are main expressions mentioned in the definition of Social Studies:

dimension of;

- Raising active citizen,

- Enculturation,

- Suitability for student,

- Knowledge-base,

- $\quad$ Method,

- Time,

- $\quad$ Field and course (Tay, 2010: 10).

\section{Comics}

According to one of the shorthest definitions of comics which has found a deep place to itself in popular culture, comics is that any story or short story is told/narrated through pictures or drawings (Alsaç, 1994: 44). Comics which is a fiction art and a narration style, consisting of combination of the writing and picture, is neither only a picture nor a writing (Ceran and Cantek, 2004: 28). The most common and accepted understanding on what comics is that it is defined as story in which connection between successive pictures is told/narrated (Özşen and Sayın 2004: 77).

\section{Material and Comics in the Teaching}

There are a lot of studies which present benefits provided by material use during learningteaching process. It is known that giving place to the teaching materials during courses makes subjects simplier and more concrete. Moreover, it helps to collect student's attention in that it appeals to more than one sense organs, and also facilitates students' motivations (Y1ld1z, 2004: 13). Visual element that is other component of comics is a strong material in supporting the teaching. Only the writing or visual material is not sufficient in the teaching alone. It is known that impact has increased only when both have been used together (İşler, 2003: 9).

There are two important components which consitute comics: the writing and picture. On comics, the writing is thought to pay the way for children's transition to academic language. The use of different kinds of the teaching material will be able to lead students' successes to increase, who have different characteristics, and this will be able to increase the success in education-teaching. Besides, with efficient usage of the teaching tools and materials, students' raising as individuals who know the ways to reach knowledge will be made (Çelikkaya, 2013: 45-47).

The teaching materials which are designed according to instructional principles and methods diversify the learning-teacher process and increase the learning (Yalın, 2009: 8290).

We can count benefits of the teaching tools and materials in terms of teacher as; contribution to teachers' enjoying from their occupations, helping them to remember 
important points, making them lecture courses more comfortably and easily, facilitating them to teach course in a more controlled way, providing them with guiding time and attention to fulfill students' personal needs, and providing saving from time and cost etc. (Çelikkaya, 2013: 50-51).

While determining whether an tool is needed or not on the learning-teaching situations, those below are taken into account and an evaluation is carried out:

- General purposes of course and subject,

- Target behaviors which show that these purposes have been reached,

- Nature of messages which are wanted to be given on course content or subjects,

- Students' situations and characteristics,

- Message, transmission, potential and limitations of tools which are useable in the teaching activities (Koşar and Çiğdem, 2003: 42).

\section{The Writing Elements in The Teaching Materials}

Usage of the writing elements consciously will build skill to be able for both students and teachers to take a lot of actions such as presenting, hiding knowledge, facilitating to remember etc., masterly and without getting bored (Yalın, 2009: 82). The most important advantages of the written materials are their being common, cheap, easily accessible and duplicable (Yanpar, 2009: 111).

\section{Visual Elements in the Teaching Materials}

Learning is acquired through experiences which are gained by eyesight of $83 \%$, sense of hearing of $11 \%$, sense of smell of $3,5 \%$, sense of touch of $1,5 \%$, and sense of taste of $1 \%$ (Koşar and Çiğdem, 2003: 37). Preferring efficient materials which will appeal to eyesight in learning is of great importance. Priorly, for lecture of course subject, the relevant basic points should be determined and visual material support should be prepared (Savaş, 2007: 160). Design elements of visual materials consist of line, area, figure, dimension, pattern and colour.

\section{Method}

In the study, we used a paradigm-based descriptive method. Events and situations in hand in descriptive studies are searched in detail and "what" they are is tried to be determined, by examining their relationship with previous situations and events (Karakaya and Tanriöğen, 2011: 59). With compiling qualitative data collected, we gave suggestions on how comics should be created for the purpose of Social Studies teaching, and with which teaching methods and techniques it should be used.

Population of the study consists of $6^{\text {th }}$ grade Social Studies course book. In this study, sample consists of achievements in the first unit of $6^{\text {th }}$ grade Social Studies course book and references in the study. A literature review concerning the study was carried out within the scope of documentary source collection. As is known, the documentary source compilation is collection and examination of data, written before, prepared and created on a subject (Seydioğlu, 1993: 40). For the purpose of data collection, we examined $6^{\text {th }}$ grade Social Studies course book and various references, for material development.

In this study where qualitative paradigm-based descriptive model was used, data obtained during the study were analyzed by a descriptive and interpretive technique. Applications were shaped over data obtained in the process and were supported by literature review. 


\section{Purpose}

Purpose of the study is to determine features which there should be in comics by generating material for achievements of Social Studies course, and to bring forward proposals for the generated materials to support the suitable teaching methods and techniques.

In this context, we will ground how comics would be generated as the teaching material, will create comics; for the unit "I Am Learning Social Studies" which is the first unit of 6th grade Social Studies course; suitable for achievements; and fulfilling criteria of the teaching materials development, and will bring forward proposals for usage of the created comics in terms of comtemporary teaching methods and techniques.

One of the most important reasons for which this study is carried out is necessity of using different methods, techniques and tool in teaching Social Studies course, and also comics' being suitable for using and creating within this scope.

This study is expected;

- $\quad$ To be source on how comics which will be generated as the teaching material that is supportive of contemporary teaching methods and techniques could be created,

- To make contribution to create comics for achievements of units which appear in Social Studies course books,

- To bring forward proposals for which kinds of teaching methods and techniques comics that are created for the purpose of social studies teaching could support,

- $\quad$ To make contribution of findings obtained as a result of the study to relevant persons and institutions.

\section{Findings}

A comics script consists of three steps as subject, treatment and scenario. In this context, we can explain three steps in comics we will create as the teaching material in the simpliest state in that way:

a. Subject (Plot): It is possible to address the subject as "achievement" in comics which will be developed for the teaching-purpose.

b. Treatment: It is section where the achievement is prepared to script and presented as a fiction. In this episode, space, time, characters and event or problem are addressed simply.

c. Scenario: It is the completely completed version of the comics in font size just before the drawing. The appearance descriptions of the characters, dialogs, page layout and the content of the frames are determined exactly.

Comics-creation process is a process that requires knowledge, imagination, authenticity, meticulousness and attention. We can follow comics-creation process in the simpliest form as follows:

- To Create Something New: First Touches by Pencil

- $\quad$ To Immortalize the Created One: To use ink

- Transfer to Digital Platform: Scanning

- $\quad$ To Adjust the Image on Digital Platform 
- To Lend Colour to Comics on Digital Platform

- $\quad$ Shadowing and Lighting

- $\quad$ Placing Speech Bubbles on Digital Platform

- $\quad$ Placing Text

- $\quad$ Making it ready for print

Comics Which Were Generated within the Frame of Achievements of Sixth Grade the Unit "I Am Learning Social Studies", and Available Teaching Methods and Techniques

In this section, place was given to achievements and comics which were developed in accordance with conditions of being the teaching material by the researcher. To have standardness, comics were designed as two pages at a time.

Achievement "Recognizes Multi-Dimensionality of An Event Based Upon An Example from His/Her Immediate Surroundings

Created according to 6th grade 1st Unit 1st achievement, this comics was designed according to the technique " to be continued tomorrow" which takes place within educational games category and "brainstorming technique" within the case method.

\section{Achievement "Distinguishes Fact and Opinion"}

Created according to 6th grade 1st Unit 2nd achievement, this comics was designed according to decision-making technique which takes place in the case method.

\section{Achievement "Does Research by Using Scientific Steps of Research"}

Created according to 6th grade 1st Unit 3rd achievement, this comics was designed according to the problem-solving method. Purpose is to prompt student to do research.

Comics Which Were Created within the Frame of Achievement "Defends That Solutions Which Were Delivered to A Problem Should Be on the Basis of Rights, Responsibilities and Freedoms"

Created according to 6 th grade 1 st Unit 4th achievement, this comics was designed according to question-answer technique.

\section{Achievement "Recognizes Contribution of Social Studies to Student's Development as An Active Citizen of Turkish Republic"}

Created according to 6th grade 1st Unit 5th achievement, this comics was designed according to acting/role playing technique within the educational games category.

Achivement "Gives Examples to Implementations Carried Out by Atatürk to develop Social Studies in Our Country"

Created according to 6th grade 1st Unit 6th achievement, this comics was designed according to circle technique within discussion method.

\section{Discussion and Conclusion}

Conclusions based on findings obtained within the scope of the study can be summarized as follows.

- To create comics which will be used for the teaching-purpose is a process that requires a serious accumulation of knowledge and creativity, 
- Comics which would be created for social studies teaching need to be generated by taking elements of comics into account in terms of the teaching,

- By following right steps, comics can be created for Social Studies teaching,

- $\quad$ Although use of comics in teaching of Social Studies course influences positively on student success, some issues need to pay attention while it is using in the teaching. As a matter of fact, it should be paid attention to the fact that comics to be used should be suitable for subject, student, and contemporary teaching methods-techniques.

- $\quad$ Comics are able to be extremely powerful teaching materials about supporting contemporary teaching methods and techniques.

- The created comics are expected for students' concerns and attitudes in course to influence positively.

- $\quad$ The created comics are expected to increase success in the subject area.

\section{Implication and Suggestions}

\section{Recommendations for Creating Comics in Social Studies Course}

- $\quad$ Social Studies teachers can create their comics for teaching-purpose with practical and professional support,

- $\quad$ Support can be received from professional writers and illustrators in creating comics for Social Studies teaching-purpose,

- While creating comics, Social Studies curriculum should be taken into consideration,

- $\quad$ Course book criteria which are specified in Ministry of National Education Regulation for Coursebooks and Educational Tools should be taken into consideration,

- Achievements which are source to comics should be examined carefully,

- $\quad$ Comics should be not only a material to be read, but also in a form that will support contemporary teaching methods and techniques,

- While creating comics, visual design principles on material design should be paid attention to,

- While developing comics, principles on the writing elements within the scope of the teaching material should be paid attention to,

- In creating comics, students' level should be taken into consideration, and no place should be given to elements which contain violence, slang and sexuality,

- $\quad$ Place should be given to so humorous elements as not getting the topic off focal point in comics,

- $\quad$ No unnecessary details should be given place in comics to be created, and message should be concentrated on,

- $\quad$ An universe should be created in comics, this created universe should not be of a very complex structure, and students should understand what is going on this universe, at first sight,

- "Choose Your Own Adventure" type comics, which will create opportunity for students to have an impact on script even limited, can be created,

- $\quad$ Also students can be included into process of comics-creation for Social Studies teaching. 


\section{Recommendations for Comics to be Implemented in Social Studies Course}

- $\quad$ Comics should not be dictated as the reading tool in the course and should be given as part of contemporary teaching methods and techniques,

techniques,

- Opportunity to experimental learning should be given to students,

- $\quad$ Students' personal comments should be respected to. As a matter of fact, each human's way of perceiving the worl is different,

- Students should be included into the process actively,

- $\quad$ Group work should be promoted,

- $\quad$ Process should be completed with evaluation suitable for update teaching methods and techniques.

\section{Research Limitations and Future Research}

The comics created within the scope of this study are limited to the achievements of the unit "I am learning Social Studies" in the 6th Grade Social Studies textbook of the Ministry of Education for the 2017-2018 academic year. Teaching methods and techniques were chosen by the researchers according to the outcomes.

\section{Author Contributions}

This study is produced from master thesis (Oluşturma ve Uygulama Açısından Sosyal Bilgiler Öğretiminde Bir Öğretim Materyali Olarak Çizgi Roman Kullanımı). Study authors include graduate student and supervisor. Both authors contributed jointly at each stage of the study. All authors have read and accepted the published version of the article.

\section{Publication Ethics}

Research and Publication Ethics was complied 